\title{
EVALUATING THE IMPACT OF REMITTANCES ON HUMAN CAPITAL INVESTMENT IN THE KYRGYZ REPUBLIC
}

Xin Gao, Aiko Kikkawa, and Jong Woo Kang

NO. 637

May 2021

\section{ADB ECONOMICS} WORKING PAPER SERIES 


\section{ADB Economics Working Paper Series}

\section{Evaluating the Impact of Remittances on Human Capital Investment in the Kyrgyz Republic}

Xin Gao, Aiko Kikkawa, and Jong Woo Kang

No. 637 | May 2021
Xin Gao (xg68@cornell.edu) is a PhD candidate at the Dyson School of Applied Economics and Management, Cornell University. Aiko Kikkawa (atakenaka@adb.org) is an economist and Jong Woo Kang (jkang@adb.org) is a principal economist at the Economic Research and Regional Cooperation Department (ERCD), Asian Development Bank (ADB).

The authors thank for their valuable comments and support Tynaliev Bakytbek, Rie Hiraoka, Steven Lewis-Workman, Candice Mcdeigan, Manisha Pradhananga, Mamatkalil Razaev, Yasuyuki Sawada, and Takashi Yamano. Contributions of other participants from an ADB ERCD seminar on 15 August 2018 and research presentations from an ADB Economist Forum on 14 January 2019 are also appreciated. The authors would also like to thank Tilman Brück and Damir Esenaliev for providing access to data from the "Life in Kyrgyzstan" survey and guidance on data collation. Cindy Justo provided excellent research assistance. 
(C) 2021 Asian Development Bank

6 ADB Avenue, Mandaluyong City, 1550 Metro Manila, Philippines

Tel +632 8632 4444; Fax +63286362444

www.adb.org

Some rights reserved. Published in 2021.

ISSN 2313-5867 (print), 2313-5875 (electronic)

Publication Stock No. WPS210189-2

DOI: http://dx.doi.org/10.22617/WPS210189-2

The views expressed in this publication are those of the authors and do not necessarily reflect the views and policies of the Asian Development Bank (ADB) or its Board of Governors or the governments they represent.

ADB does not guarantee the accuracy of the data included in this publication and accepts no responsibility for any consequence of their use. The mention of specific companies or products of manufacturers does not imply that they are endorsed or recommended by ADB in preference to others of a similar nature that are not mentioned.

By making any designation of or reference to a particular territory or geographic area, or by using the term "country" in this document, $A D B$ does not intend to make any judgments as to the legal or other status of any territory or area.

This work is available under the Creative Commons Attribution 3.0 IGO license (CC BY 3.0 IGO)

https://creativecommons.org/licenses/by/3.0/igo/. By using the content of this publication, you agree to be bound by the terms of this license. For attribution, translations, adaptations, and permissions, please read the provisions and terms of use at https://www.adb.org/terms-use\#openaccess.

This CC license does not apply to non-ADB copyright materials in this publication. If the material is attributed to another source, please contact the copyright owner or publisher of that source for permission to reproduce it. ADB cannot be held liable for any claims that arise as a result of your use of the material.

Please contact pubsmarketing@adb.org if you have questions or comments with respect to content, or if you wish to obtain copyright permission for your intended use that does not fall within these terms, or for permission to use the ADB logo.

Corrigenda to ADB publications may be found at http://www.adb.org/publications/corrigenda.

Note:

ADB recognizes "China” as the People's Republic of China and "Kyrgyzstan” as the Kyrgyz Republic.

The ADB Economics Working Paper Series presents data, information, and/or findings from ongoing research and studies to encourage exchange of ideas and to elicit comment and feedback about development issues in Asia and the Pacific. Since papers in this series are intended for quick and easy dissemination, the content may or may not be fully edited and may later be modified for final publication. 


\section{CONTENTS}

TABLES AND FIGURE iv

ABSTRACT

$\begin{array}{lll}\text { I. INTRODUCTION } & 1\end{array}$

$\begin{array}{ll}\text { II. } & \text { LITERATURE REVIEW }\end{array}$

A. Migration, Remittances, and Educational Investment 3

B. Existing Literature in the Kyrgyz Republic and Other Central Asian Countries 4

$\begin{array}{ll}\text { III. DATA } & 5\end{array}$

$\begin{array}{lll}\text { IV. } & \text { ESTIMATION STRATEGY AND RESULTS } & 8\end{array}$

A. $\quad$ Fixed Effects Panel Regression 9

B. Regression with Instrumental Variables 10

C. Estimation Results (1): Remittances and Human Capital Investment 11

D. Estimation Results (2): Remittances and Educational Outcomes 15

$\begin{array}{llr}\text { V. CONCLUSION } & 23\end{array}$

$\begin{array}{ll}\text { APPENDIX } & 25\end{array}$

$\begin{array}{lc}\text { REFERENCES } & 33\end{array}$ 


\section{TABLES AND FIGURE}

\section{TABLES}

$1 \quad$ Household Finance Summary Statistics 6

2 Remittances Receiving and Nonreceiving Households Comparison $\quad 7$

3 Remittance Trends, by Region $\quad 7$

4 Education Enrollment Rate, by Age Group 8

$5 \quad$ Effect of Remittances on Education Expenditure 12

6 Effect of Remittances on Other Household Expenditure (FE, IV) 14

7 Effect of Per Capita Remittances on Attendance Rate, by School Level 16

8 Effect of Per Capita Remittances on Attendance Rate, by Compulsoriness 17

9 Effect of Per Capita Remittances on Children's Time-Use Pattern 19

10 Effect of Remittances on Attendance Rate, by Gender 21

11 Effect of Remittances on Time Use, by Gender 22

A1 Reliance on Remittances $\quad 25$

A2 Summary Statistics for Regression Variables 25

A3 Education Expenditure Comparison: Receiving and Nonreceiving Families 27

$\begin{array}{lll}\text { A4 First-Stage Results } & 28\end{array}$

A5 Itemized Household Expenditure $\quad 29$

A6 Correlation Matrix $\quad 30$

A7 Effect of Remittances on Other Household Expenditure (OLS) 31

A8 Effect of Per Capita Remittances on Attendance Rate, by School Level (OLS) 32

\section{FIGURE}

1 Top 10 Remittance-Recipient Economies in Asia, 2017 


\begin{abstract}
Remittances from overseas can encourage human capital investment and improve educational outcomes in developing countries. Empirical studies, however, have shown mixed evidence at best. This paper uses a 5-year panel dataset that tracks the same 3,000 households and 8,000 individuals through time in all seven regions of the Kyrgyz Republic to examine the impact of remittances on the human capital formation of school-age children. After correcting for selection bias and other potential endogeneities with instrumental variables and fixed effects regressions, remittances are found to have negative impacts on human capital investment and educational achievement. The negative effects can be attributed in part to recipients' increased expenditure on durable goods and extended hours of child labor on farm work as a compensation for missing adult labor. Our finding calls for actions that mitigate the negative effects and incentivize families to spend remittances on education, including financial literacy education, better monitoring of farm labor hours of school-age children, and targeted investment to improve the quality of education services in the Kyrgyz Republic.
\end{abstract}

Keywords: education, household expenditure, human capital investment, Kyrgyz Republic, labor migration, remittances

JEL codes: D13, F22, F24, O15 


\section{INTRODUCTION}

Remittances from international migrants are a major resource for economic development in many countries. In the short term, remittances contribute to improving the livelihood of recipient households and protect against economic shocks, including from natural disasters (Adams 2006; Acosta, Fajnzylber, and Lopez 2007; Gupta, Pattillo, and Wagh 2009). In the long term, remittances can encourage investments in local businesses and community development with sustained developmental effect. For countries consisting of large youth populations with low education attainment, channeling remittances into human capital investment is especially important. Empirical evidence on such effects, however, has been mixed. Adams and Cuecuecha (2010) found strong positive effects in Guatemala, while McKenzie and Rapoport (2011) found negative effects in Mexico, and Ang, Sugiyarto, and Jha (2009) found no significant effects in the Philippines.

A reasonable explanation for the above seemingly contradictory evidence is provided by McKenzie and Rapoport (2011). On one hand, the inflow of remittances helps to relax households' budget constraints, allowing more resources to be directed toward education. On the other hand, outmigration reduces the adult labor force in a household, which may lead to increased child labor, especially if labor market is underdeveloped. Along with the array of individual and household characteristics (e.g., a child's gender, age, number of siblings, family structure, and the educational attainment of their parents), country-specific factors (e.g., the education system, labor market condition, and legal and institutional frameworks) may add complexity to this relationship, as do the channels through which the effects are realized. The study of this research topic therefore requires deep contextual investigation.

In this paper, the impacts of remittances on human capital investment and educational outcome of the Kyrgyz Republic are estimated using a 5-year panel data. The Kyrgyz Republic depends on remittances heavily: in 2017, its total remittance receipts as a share to the gross domestic product were the highest among countries in Asia and the Pacific, at 34.7\% (Figure 1). ${ }^{1}$ Per capita remittances in the same year were also high, suggesting they could bring substantial impacts to the country's economy and households. Moreover, the Kyrgyz Republic has a young population, with a median age of 26.5 years. Investment in human capital is therefore crucial for its future development. To date, empirical evidence is both scant and mixed as to whether a large inflow of remittances is helping the country build human capital (Kroeger and Anderson 2014; World Bank 2015; Hagedorn, Wang, and Chi 2017). The question needs to be revisited with richer, updated data.

\footnotetext{
1 Using national statistical information from the National Bank of the Kyrgyz Republic, the ratio is $26.4 \%$ in the same year.
} 


\section{Figure 1: Top 10 Remittance-Recipient Economies in Asia, 2017}

(a) as \% to GDP

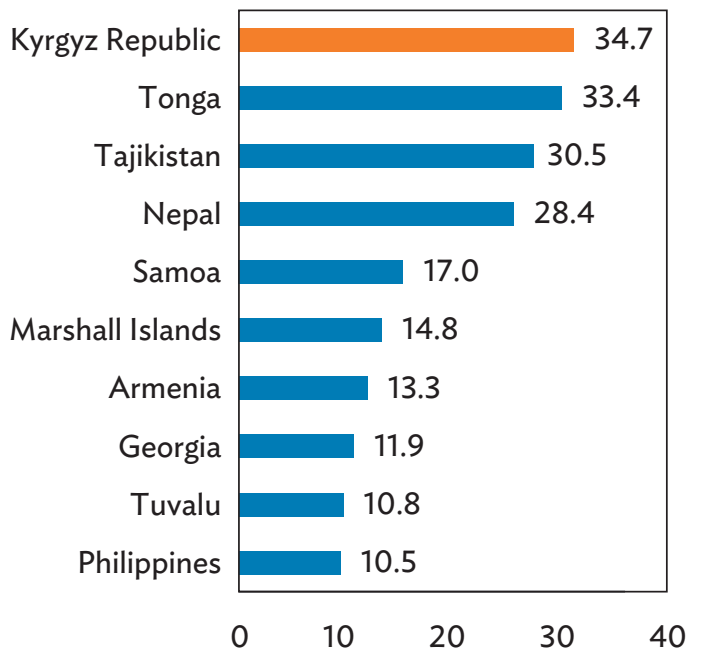

(b) per capita (\$)

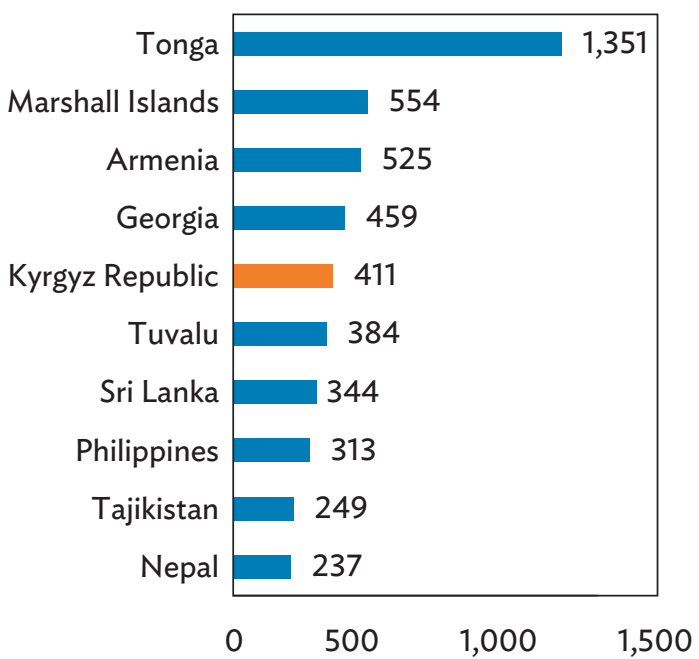

GDP = gross domestic product.

Note: Per capita refers to the remittance per person of total population.

Source: ADB calculations using data from the Global Knowledge Partnership on Migration and Development. http://www.knomad.org/data/remittances (accessed May 2018).

Empirical identification of the causal effect of remittances on human capital investment is known to be a challenge due to the endogenous nature of migration decisions and remittance volume. To overcome this, we first take advantage of the panel nature of the data to eliminate time-invariant unobserved heterogeneity at household and the members levels. Furthermore, to correct for the potential bias caused by simultaneity (the possibility that higher educational expenditure induces higher remittances), we use a set of instrumental variables (e.g., distance to road and other amenities, interaction between land area and incidences of drought) in panel regressions. With these empirical treatments, this paper finds that remittances have a negative impact on human capital investment and educational achievement in the Kyrgyz Republic. Both educational expenditure and school enrollment rates are lowest among households that receive the highest remittances. To explore the possible channels of the negative effects, we examine how remittances affect other household expenditures and how school-age children use their time. The paper finds that the negative effects can be at least partly attributed to the increased expenditure on durable goods and hours of child labor induced by migration and remittances.

We believe that the study contributes to ongoing research on the impact of migration and remittances on household human capital investment. It offers a rigorous case study of a country that is highly dependent upon remittances yet has received scarce empirical focus to date to help draw conclusions. The rest of the paper is structured as follows. Section II reviews the previous literature on relevant fields. Section III introduces the dataset used in this study (Life in Kyrgyzstan) and provides descriptive statistics. Section IV presents the identification strategy, instrumental variables used, and estimation results. Section $\vee$ discusses policy implications along with the limitations of the study, and concludes. 


\section{LITERATURE REVIEW}

The process by which migration and remittance inflows affect human capital investment and educational attainment is complex. It involves a range of social and economic values and preferences, and is characterized by heterogenous outcomes across jurisdictions, sectors, and individual and household characteristics. Further, remittances and the migration process impact the education of children and youth left behind through different channels. Indeed, existing studies show that the net effect of remittances and international migration on human capital investment is ambiguous and heterogeneous at best.

\section{A. Migration, Remittances, and Educational Investment}

According to Hanson and Woodruff (2003), remittances may have both positive and negative effects on the educational attainment of school-age children, which also could be contingent upon gender. For example, parents may choose to provide greater access to education for boys in a country where sons usually bear greater obligation to support elderly parents. Yet, boys are also a better substitute for lost farm labor due to migration and may be required to forgo education and instead work more when adults are absent.

Some empirical studies support the positive contribution of migration and remittances to educational outcomes. Remittances relax households' liquidity constraints and fund the direct and opportunity costs of schooling (Cox-Edwards and Ureta 2003; Lu and Treiman 2007; Yang 2008; Calero, Bedi, and Sparrow 2009; Adams and Cuecuecha 2010; Acosta 2011; Acharya and LeonGonzalez 2014; Bui, Le, and Daly 2015). Ultimately, these and other studies conclude that higher income from remittances raises school enrollment, attendance, and completion rates; lowers dropout rates; and improves the quality of education (Hanson and Woodruff 2003; López-Córdova 2006; Mansuri 2006; Bansak and Chezum 2009; Bredl 2011; Koska et al. 2013; Salas 2014; Bouoiyour, Miftah, and Mouhoud 2016).

Other studies find negative effects on child education attainment, stemming from the disruptive effects of family migration and associated factors. For one, negative effects might be driven by the increased demand for child labor to fill the gap in domestic responsibilities left by the household member who migrated (e.g., Amuedo-Dorantes and Pozo 2010; Antman 2011; Frisancho Robles and Oropesa 2011; McKenzie and Rapoport 2011; Alcaraz, Chiquiar, and Salcedo 2012; Kroeger and Anderson 2014). Moreover, if jobs for migrants are low skilled, then the left-behind children may discount the value of education, potentially causing them to settle for low educational attainment. This is reinforced within communities with a high prevalence of international migration. A "culture of migration" can develop, such that young people are expected to migrate to achieve socioeconomic mobility (Kandel and Massey 2002, Halpern-Manners 2011, McKenzie and Rapoport 2011).

Further, some studies point to conspicuous consumption among migrant households that characterizes a trade-off between productive and consumptive investment. ${ }^{2}$ For instance, based on a

2 Following the logic of Chami, Fullenkamp, and Jahjah (2003), De Brauw and Rozelle (2008), and Yang (2008), among others, consumptive investments include investments in housing and durable goods, while productive investments include investments in physical or human capital aimed to increase households' income-earning potential (such as in education, agriculture, or business). 
review of cross-country case studies, Chami, Fullenkamp, and Jahjah (2003) find a significant proportion, and often most of the remittances are spent on "status-oriented" consumption goods. Stephenson and Wilsker (2016) also show that the effects of remittances are largest in the areas of luxury expenditures and building houses, and to a lesser extent for education and buying essential household goods. These and other studies (Zhang et al. 2014, World Bank 2015) underline the adverse impacts of the absence of parental guidance, low returns to education (both in origin and destination countries), and idiosyncrasies among countries in education investment and acquisition as potential causes of this trade-off.

Notwithstanding the discourse on the overall causality direction of migration and remittances on educational expenditure and outcome, the literature suggests the magnitude of these effects may vary according to specific sociodemographic characteristics and is contingent upon or influenced by the interplay among diverse factors. Some studies find that the positive effects of economic migration and remittances on human capital accumulation can be much greater for boys than girls, whereas others point to a pattern favoring girls (Mansuri 2006, Bansak and Chezum 2009, Acosta 2011). Moreover, other studies provide evidence of the interaction between gender and environment differentials, finding positive effects skewed toward urban males and negative effects falling mainly on rural female children (Bucheli, Bohara, and Fontenla 2018). Similarly, some studies note the impact of the migration-remittance process on educational investment is heterogeneously positive, but most evident among children of secondary school age, with younger siblings standing to gain the most (Amuedo-Dorantes and Pozo 2010, Acharya and Leon-Gonzales 2014). Among other factors, this can be attributed to the negligible direct costs of schooling for children of primary school age in the free public schooling system.

These mixed results partly reflect shortcomings in the identification strategies among existing studies; many do not fully account for potential endogeneity and reverse causality (McKenzie and Yang 2010), although some control for the endogeneity by use of either a variety of instrumental variables or natural experiment. Across these studies, instrumental variable technique is the most commonly employed method, yet the instruments must be carefully selected based on exclusion restriction assumptions to avoid biased estimates (Gibson, McKenzie, and Stillman 2013). In this regard, the preference has been to rely on natural experiment, in which using large exogenous movement in foreign exchange rates as a source of variation (Yang 2008) and migration facilitated through a visa lottery scheme (Gibson, McKenzie, and Stillman 2013) have proven to be good examples. Another strand of effective method has employed panel data analysis (Lall, Harris, and Zmarak 2006; Yang 2008: Quisumbing and McNiven 2010; Funkhouser 2013; Böhme 2015; Kikkawa, Matsumoto, and Otsuka 2019). The study in this paper is based on panel data analysis and engaging a reliable instrumental variable technique.

\section{B. Existing Literature in the Kyrgyz Republic and Other Central Asian Countries}

Several empirical studies have examined the impact of remittances on overall welfare and certain household outcomes in the Kyrgyz Republic. For instance, Karymshakov, Abdieva, and Sulaymanova (2014) find that international remittances considerably decrease poverty. In terms of specific household outcomes, Muktarbek kyzy, Seyitov, and Jenish (2015) analyze the impact of international migrants' remittances on the expenditure structure of households using the Life in Kyrgyzstan survey for 2010-2012 and demonstrates that remittances increase the share of expenditures on construction, celebrations, and durable goods, but decrease the shares of expenditure on food and public utilities. 
The findings of Muktarbek kyzy, Seyitov, and Jenish (2015) are consistent with studies by Ukueva and Becker (2010), who conclude that remittances increase durable goods consumption, and with Hagedorn, Wang, and Chi (2017), who find that increases in household remittance receipts are correlated with spending smaller share of the household budget on food and housing and a larger share on events and other expenses (such as legal and educational expenses).

Studies on the impact of international migration and remittances on human capital investment-particularly on education-in Central Asia is quite limited. Brown, Olimova, and Boboev (2008) find that school absenteeism increases with remittances in Tajikistan and can be explained by recipients' low confidence about the future returns of investment in education and good employment opportunities. By contrast, Anderson and Mirkasimov (2010) find positive effects in overall education expenditure in Tajikistan, as well as in the school enrollment of older children.

A study by Kroeger and Anderson (2014) on the Kyrgyz Republic is the most relevant to this paper. It evaluates the impact of remittances (domestic and international transfers combined) on the probability of school enrollment using fixed effects and instrumental variable technique. The study, based on data collected from 2005 to 2009, finds that the receipt of remittances has no significant impact on overall school enrollment, with negative and significant effect on children of ages 14-18, especially boys. The negative impact is mainly due to the household losing adult labor. Our study aims to complement this study with contributions in four areas: (i) isolating the effect of international remittances from that of domestic transfer, (ii) providing analysis based on an alternative and updated panel dataset extending the period up to 2016, and (iii) introducing additional and more direct outcome variables (educational expenditure) besides school enrollment data, ${ }^{3}$ and (iv) identifying channels through which remittances may affect educational expenditure and outcomes-for example, spending on other goods and changes in how children use their time.

\section{DATA}

Data used in this paper is from The Life in Kyrgyzstan Study, ${ }^{4}$ a longitudinal survey that tracks the same 3,000 households and 8,000 individuals over time in all seven Kyrgyz Republic regions (the oblasts of Batken, Jalal-Abad, Issyk-Kul, Naryn, Osh, Talas, and Chui) and the cities of Bishkek and Osh. The data are representative at the national and regional levels (North, Central, and South). The survey interviews all adult household members about household demographics, assets, expenditure, migration, employment, agricultural markets, shocks, social networks, subjective well-being, and many other topics. The survey was first conducted in the fall of 2010 and has been repeated four times: in 2011, 2012, 2013, and 2016. All household members first interviewed in 2010 are tracked and interviewed again later. If a member of an original sample household leaves the household (e.g., to form an own family), he or she is still part of the sample. If relevant, other members (e.g., a spouse and children) of the new household are included in the sample. By the end of the last wave in 2016, the attrition rate for households is about $20 \%$.

\footnotetext{
3 World Bank (2015) explores the impact of international remittances on educational expenditure using ordinary least squares (OLS) regression, but the study does not control for potential endogeneity.

4 The Life in Kyrgyzstan Study can be accessed at https://lifeinkyrgyzstan.org/.
} 
The survey consists of a household questionnaire (filled in by the most informed household member), an individual questionnaire (filled in by all members of ages 18 and above in the sampled households), and a community questionnaire (filled in by a representative of a local administration). The analysis utilizes all relevant components of the dataset by merging data across years and modules to create a 5-year unbalanced panel.

Table 1 provides basic summary statistics on the scope of the study, drawn from Life in Kyrgyzstan data. Within the timespan of this study, both household income and education expenditure increased steadily. With regard to international remittances, the percentage of households receiving remittances increased slightly from 2010 to 2013 and by 2016 had dropped to its starting level. Although the percentage of households receiving remittances was only about $10 \%$, and therefore lower than in other Asian countries, the receiving households rely heavily on remittances. Remittances on average account for about $70 \%$ of the recipient households' annual income (Table A1). Regardless of measurements used (total versus per capita; cash versus "in-kind"), the amount of remittances received varied greatly over the years. This is likely to be due to exchange rate fluctuation and unstable economic conditions in the Russian Federation during this period, given that most Kyrgyz Republic migrants work in the Russian Federation.

Table 1: Household Finance Summary Statistics

(Som)

\begin{tabular}{lccccc}
\hline & $\mathbf{2 0 1 0}$ & $\mathbf{2 0 1 1}$ & $\mathbf{2 0 1 2}$ & $\mathbf{2 0 1 3}$ & $\mathbf{2 0 1 6}$ \\
\hline Per capita household income & $2,847.01$ & $2,970.17$ & $3,531.47$ & $3,988.62$ & $6,042.15$ \\
Percentage received remittances from abroad & $10.0 \%$ & $12.1 \%$ & $12.9 \%$ & $13.9 \%$ & $10.4 \%$ \\
Total annual amount of cash remittances & 7,587 & 24,188 & 22,424 & 16,533 & 18,295 \\
$\begin{array}{l}\text { Total annual amount of cash remittances } \\
\text { (receiving households only) }\end{array}$ & 75,867 & 200,721 & 175,345 & 119,507 & 175,989 \\
Total annual amount of in-kind remittances & 28.67 & 87.39 & 124 & 111.1 & 83.99 \\
Per capita annual remittances & 1,420 & 4,232 & 4,429 & 2,771 & 2,798 \\
Household education expenditure (primary) & 2,044 & 2,622 & 2,980 & 3,781 & 4,446 \\
Household education expenditure (secondary) & 2,826 & 3,701 & 4,045 & 5,249 & 5,444 \\
Number of observations & 3,000 & 2,863 & 2.815 & 2,566 & 2,530 \\
\hline
\end{tabular}

Source: The Life in Kyrgyzstan Study data (accessed June 2018); Authors' calculation.

Table 2 compares the household characteristics of recipient and nonrecipient households. As shown in the last column, the two groups are statistically significantly different in all aspects. On the one hand, households that receive remittances benefit from higher household income and are likely to have more male and married household heads than those that do not. However, they are simultaneously at a disadvantage through having less educated household heads and being more likely to be located in rural areas. These differences may affect how recipient households perceive the importance of human capital investment and how they allocate resources between production and education, in both money and time. 
Table 2: Remittances Receiving and Nonreceiving Households Comparison

\begin{tabular}{lccc}
\hline Variables & Nonrecipient & Recipient & Difference \\
\hline Household size & 4.676 & 6.536 & $-1.860^{* * *}$ \\
Household income (soms) & 18,000 & 22,000 & $-4.3 e^{+0} 03^{* * *}$ \\
Male household head & $71.20 \%$ & $76.80 \%$ & $-0.056^{* * *}$ \\
Household head age & 51.67 & 54.57 & $-2.896^{* * *}$ \\
Household head education (years) & 4.72 & 4.412 & $0.308^{* * *}$ \\
Household head married & 0.701 & 0.78 & $-0.080^{* * *}$ \\
Rural households & $58.10 \%$ & $74.30 \%$ & $-0.161^{* * *}$ \\
Observations & 12,144 & 1,630 & \\
\hline
\end{tabular}

Note: ${ }^{* *} p<0.01,{ }^{* *} p<0.05,{ }^{*} p<0.1$.

Source: The Life in Kyrgyzstan Study data (accessed June 2018); Authors' calculation.

Interestingly, geographic variations across regions in the Kyrgyz Republic are huge. As shown in Table 3, households in the South are more reliant on remittances than those in the North and Central areas. Moreover, households in the South have more migrants per household: more than $20 \%$ also receive remittances, and the amounts are much higher compared to other areas.

Table 3: Remittance Trends, by Region

\begin{tabular}{|c|c|c|c|c|c|}
\hline & 2010 & 2011 & 2012 & 2013 & 2016 \\
\hline \multicolumn{6}{|l|}{ North (Talas, Naryn, Issyk-Kul) } \\
\hline Number of migrants per household & 0.0476 & 0.0643 & 0.0972 & 0.12 & 0.0963 \\
\hline Received remittances & $3.43 \%$ & $4.09 \%$ & $5.36 \%$ & $8.02 \%$ & $6.56 \%$ \\
\hline Total annual amount of cash remittances & 2,691 & 5,327 & 5,640 & 7,134 & 6,508 \\
\hline Total annual amount of 'in-kind' remittances & 7.62 & 70.18 & 99.21 & 42.19 & 43.76 \\
\hline Per capita annual remittances & 521 & 1,018 & 1,316 & 1,377 & 1,268 \\
\hline \multicolumn{6}{|l|}{ Central (Chui, Bishkek City) } \\
\hline Number of migrants per household & 0.053 & 0.0418 & 0.0428 & 0.0457 & 0.0491 \\
\hline Received remittances & $2.61 \%$ & $2.85 \%$ & $2.14 \%$ & $1.81 \%$ & $3.15 \%$ \\
\hline Total annual amount of cash remittances & 2,225 & 4,792 & 3,458 & 1,379 & 3,225 \\
\hline Total annual amount of 'in-kind' remittances & 7.391 & 14.25 & 0 & 0 & 0 \\
\hline Per capita annual remittances & 495 & 995 & 803 & 273 & 639 \\
\hline \multicolumn{6}{|l|}{ South (Osh, Jalal-Abad, Batken) } \\
\hline Number of migrants per household & 0.336 & 0.357 & 0.441 & 0.429 & 0.288 \\
\hline Received remittances & $19.00 \%$ & $22.80 \%$ & $24.50 \%$ & $24.20 \%$ & $16.40 \%$ \\
\hline Total annual amount of cash remittances & 14,180 & 47,430 & 44,214 & 30,269 & 31,911 \\
\hline Total annual amount of 'in-kind' remittances & 55.47 & 153.7 & 233 & 211.7 & 150.7 \\
\hline Per capita annual remittances & 2,579 & 8,138 & 8,558 & 4,976 & 4,692 \\
\hline
\end{tabular}

Source: The Life in Kyrgyzstan Study data (accessed June 2018); Authors' calculation. 
To a large extent, the school system in the Kyrgyz Republic continues to follow the Soviet model. Education is compulsory for the first 9 years, from about ages 6-7 to age 15. Following an optional period at a private or state kindergarten, children enroll in primary school for 4 years (ages 6-7 to 9). Secondary education is divided into 5 years of basic secondary (ages 10-15) and higher secondary (ages 16-17). ${ }^{5}$ Compulsory education is provided at state institutions free of cost. Upon completing secondary education, a small portion of students would proceed to either vocational or tertiary education. Technical and vocational education and training (TVET) in the Kyrgyz Republic includes two levels-primary and secondary. The Agency for Vocational Education is responsible for primary TVET, while secondary TVET is directly under the Ministry of Education and Science. Primary TVET is provided in lyceums to train skilled workers for occupations, and secondary TVET in colleges to prepare specialized technicians. Standard entry into both programs follows completion of grade 9 , with a typical program lasting 3 years. However, unstructured variations have developed-for example, primary TVET courses are offered for durations of 1 year or less. ${ }^{6}$

For simplicity, we include TVET into the secondary category as it is not administered through the university system. Tertiary education delivers a bachelor's degree in 4 years, which allows students to pursue master's programs lasting 2 years. PhD programs are offered at some institutes as well. Average enrollment rates for each schooling drawn from the Life in Kyrgyzstan surveys are summarized in Table 4. Primary and secondary education enrollment rates of about $90 \%$ are high and stable. The primary education enrollment rate is lower than that of secondary education because some children of age 6 may be considered preschool and may start schooling the next year, as shown in the last row of Table 4, where the enrollment rate for children of age 6 is especially low. The enrollment rate for postsecondary education hovers around $20 \%$. This is likely because postsecondary education is neither compulsory nor free of charge. Postsecondary education take-up remains low and is on the decline.

Table 4: Education Enrollment Rate, by Age Group

(\%)

\begin{tabular}{lcccccc}
\hline & $\mathbf{2 0 1 0}$ & $\mathbf{2 0 1 1}$ & $\mathbf{2 0 1 2}$ & $\mathbf{2 0 1 3}$ & $\mathbf{2 0 1 6}$ & Overall \\
\hline Ages 6-9 & 87.4 & 88.4 & 84.9 & 85.3 & 89.5 & 87.2 \\
Ages 10-17 & 93.0 & 91.9 & 91.6 & 92.6 & 96.1 & 92.9 \\
Ages 18-24 & 23.4 & 21.3 & 19.5 & 14.7 & 17.4 & 19.3 \\
Age 6 & 46.4 & 48.4 & 38.7 & 35.1 & 59.3 & 46.4 \\
\hline
\end{tabular}

Source: The Life in Kyrgyzstan Study data (accessed June 2018); Authors' calculation.

\section{ESTIMATION STRATEGY AND RESULTS}

The impact of remittances on the education of school-age children in recipient households is estimated using educational expenditures and school attendance as two outcome variables. Two potential sources of endogeneity may bias the outcomes. First, time-invariant unobserved characteristics among households (neighborhood environment, beliefs about the importance of

5 Education category classification drawn from https://www.scholaro.com/pro/countries/Kyrgyzstan/Education-System.

6 Skills for Inclusive Growth Sector Development Program: Report and Recommendation of the President

(https://www.adb.org/projects/documents/kgz-50024-002-rrp). 
education, and so on) and among individuals (ability, personality, and so on) may be correlated with migration, remittances, and educational outcomes. This problem is addressed with a fixed effects panel regression method to difference out these factors (section IV.A). Secondly, time-variant unobserved factors and reverse causality-the possibility that higher school costs may prompt family members to remit more-cannot be addressed by fixed effects alone. An instrumental variable approach is therefore used to achieve cleaner identification (section IV.B).

\section{A. Fixed Effects Panel Regression}

The amount of remittances received, the choice to migrate, and decisions about human capital investment may be simultaneously affected by unobserved household characteristics, such as the members' latent ability, their beliefs about the importance of education, and neighborhood characteristics. Similarly, a child's unobserved ability and personality may be correlated with both parents' migration decisions and the probability of the child attending school. Such endogeneity, left uncorrected, can lead to biased estimate. We therefore exploit the panel feature of our data and use a fixed effects model to eliminate time-invariant unobserved household characteristics. More specifically, our education expenditure regression model can be written as,

$$
\ln \left(y_{j t}\right)=\alpha_{0}+\alpha_{j}+\beta \cdot \text { Remmit }_{j t}+\delta \cdot X_{j t}+\gamma_{t}+\varepsilon_{j t}
$$

where the dependent variable $\ln \left(y_{j t}\right)$ is the natural log of the educational expenditure (up to secondary education only) of household $j$ in year $t$. The key independent variable Remmit $_{j t}$ - the amount of remittances received by household $j$ in year $t$-takes two forms in our specification: the natural log of total remittances received by the household and the natural log of per capita remittances. The log-log specification conveniently gives the coefficient an elasticity interpretation. In addition, $\alpha_{j}$ is an $j \times 1$ vector capturing household-specific time-invariant fixed effects. $X_{j t}$ is a matrix of control variables, including characteristics of the household head (gender, age, education level, marital status, and ethnicity); household size; and house value, which is employed as a proxy for wealth. $\gamma_{t}$ captures year fixed effects.

For our educational outcome specification, the likelihood of a child attending school is a function of household remittances, a vector of individual child characteristics (age), household characteristics (gender, age, education level, marital status, and ethnicity of the household head, household size, and house value). Namely,

$$
S_{i j t}=\alpha_{0}+\alpha_{i}+\beta \cdot \text { Remmit }_{j t}+\delta \cdot C_{i t}+\delta \cdot X_{j t}+\gamma_{t}+\varepsilon_{i j t}
$$

where $S_{i j t}$ is a binary indicator that takes the value of 1 if child $i$ (ages 5-24, a range that covers primary schooling to a master's education) in household $j$ is in education in time period $t$. Same as the human capital investment specification, Remmit R $_{j t}$ is the amount of remittances received by household $j$ in year $t$ and is included either as the logarithm transformation of total remittances or per capita remittances. We report results from per capita remittances specifications in the regression tables. $C_{i t}$ is the child's characteristics (age is the only time variant in the data), and $\alpha_{i}$ is an $i$ x 1 vector capturing child-specific time-invariant fixed effects. $X_{j t}$ and $\gamma_{t}$ are the same as defined in the equation (1). Descriptive data of the variables used in estimation are found in Table A2. Descriptive data on educational expenditure by remittance receiving status show that no receiving household spends more on total and most subitems of education expenditures, including tuition and school supplies, in all survey years (Table A3). 


\section{B. Regression with Instrumental Variables}

Although the fixed effects model partials out the effects of time-invariant unobservable and alleviates omitted variable bias, the endogeneity problem is not fully addressed because of the following two reasons. First, we cannot preclude the existence of time-variant omitted variables affecting the level of remittances received, human capital investment, and educational outcomes. Secondly, the need to invest more in education may trigger an increase in remittances. To address these problems, we use a set of instrumental variables to correct for potential endogeneity bias. Existing literature has identified variables such as distance to railroad lines, historical migration rates, exogenous shocks to agricultural production such as changes in rainfall patterns (e.g., Hanson and Woodruff 2003, Munshi 2003, Passel 2006, McKenzie and Rapoport 2007, Woodruff and Zenteno 2007) as valid instrumental variables. We focus on these variables and modify the specifications according to the context of our regressions.

Three sets of instrumental variables are used in our analysis, one at a time depending on the context of the regressions. The first is land area interacted with severity of drought (no drought $=0$; mild drought $=0.5$; severe drought $=1$ ), where the incidence and severity of drought is self-reported by each household. The analysis draws on Munshi (2003), who used rainfall in the origin community (collected from local weather stations) as an instrument for the size of the migrant network at the destination, the reason being that low rainfall at the origin increases the probability that the migrant will work in a nonagricultural job. Similarly, Yang and Choi (2007) used rainfall shocks to instrument for income and remittances in the Philippines.

In our case, the drought may lead to increased out-migration due to reduced farm jobs and higher remittances required to compensate for reduced income from agricultural production. By interacting land area and severity of drought, we aim to measure the impact of the disaster more accurately, since larger farms suffer heavier losses from the drought. One shortcoming with the use of natural disasters as an instrumental variable in remittance studies is potential violation of the exclusion restriction: Although drought or rainfall are exogenous shocks that affect remittances, they may also affect household expenditures directly. Whereas we acknowledge this possibility, educational expenditure, is less likely to vary with unpredictable natural disasters. Tuition payment is made with long intervals of school semester and that human capital investment decision is often made in longterm plan and with relatively hard commitment. Further, this set of instrumental variables is used only when the dependent variable is educational expenditure.

The second instrumental variable is household's self-reported distance to the nearest road. This type of instrument has been used in the existing literature, for example, by Woodruff and Zenteno (2007) for the case of Mexico and by Adams and Cuecuecha (2010) for Guatemala. Their rationale is that distance to the nearest transportation system is a good proxy for migration costs: the further a household is from the transportation system, the lower the likelihood any household member would migrate-and hence, lower remittances. Another aspect of road access is the effect of economic isolation. Namely, the further away a household is to the nearest road, the harder it is to access markets for goods and labor. This might drive household members to migrate in search for more economic opportunities. Since the cost of road access is a tiny fraction of the cost of accessing the Russian Federation labor market through air transport, we expect the isolation effect to dominate the transportation cost effect. Table A4 shows a positive coefficient on "distance to road," which confirms our conjecture. 
One potential drawback is that distance to the nearest road tends to be time invariant. In our dataset, however, there is not enough within-subject variation to allow for identification. The change may either be induced by construction of new roads or by households moving to new locations. This instrument is used for the regression of other household expenditures on remittances, since distance to the nearest road is unlikely to be correlated with expenditures on durable goods, food, weddings, other nondurable goods, and services.

For the estimation of the impact of remittances on school attendance, distance to the nearest road may not be a valid instrument as it is likely to directly affect the cost of children's daily commute to school and is therefore likely to be correlated with both educational expenditure and school attendance. We therefore introduce the third instrument-the average distance from the household to the nearest road, market, town hall, and hospital. The average distance also drives migration decisions through effects and at the same time removes the correlation with school attendance.

The first-stage regression results are found in Table A4. For each regression, the instrumental variable included is statistically significant $(p<0.001)$ on its own. Moreover, all three first-stage regressions are significant $(p<0.10)$ and have passed the weak instrumental variable tests. In the results section for our main regressions, the fixed effect panel regression results are reported two ways: without correcting for endogeneity (columns labeled "FE") and with endogeneity corrected (columns labeled "FE, IV") to allow for side-by-side comparison. For auxiliary regressions that aim to identify the channels of the impact of remittances, only the robust results (FE, IV) are reported.

\section{Estimation Results (1): Remittances and Human Capital Investment}

The estimation results for the effect of remittances on human capital investment, measured by household level educational expenditure, are summarized in Table 5. The ordinary least squares (OLS) regression results and fixed effects panel regression results without using instrumental variables are presented in columns (1), (2), (4), and (5), whereas the endogeneity corrected results are presented in columns (3) and (6). The first three columns use the natural log of total remittances received by the household as the independent variable, while the remaining columns use the natural log of per capita remittances received by the household.

Comparison of fixed effect results to that of OLS indicates that a possible direction of omitted variable bias, owning to unobserved time-invariant characteristics of household and the members, on the remittance estimator is the overestimation of the negative effects (on education expenditure) when total remittance is concerned. However, the similar effect was not observed when per capita remittance is used. Introduction of instrumental variable in the estimation augments the negative effect of remittances by a large margin. It suggests that a possible direction of endogeneity was toward the underestimation of negative effects which equates to the overestimation of positive effects. One possible explanation, as mentioned earlier, could be that large education expenditure invites large remittances.

Remittances have no effect on household educational expenditure. That is, households that receive more remittances does not spend more on the education of children. The fixed effect estimates show negative and significant effect of remittance on investment in education. Educational expenditure is also affected by household characteristics. For example, older household heads tend to spend more on children's education than younger household heads, and wealthier households (proxied by market value of the house) have higher educational expenditure. 


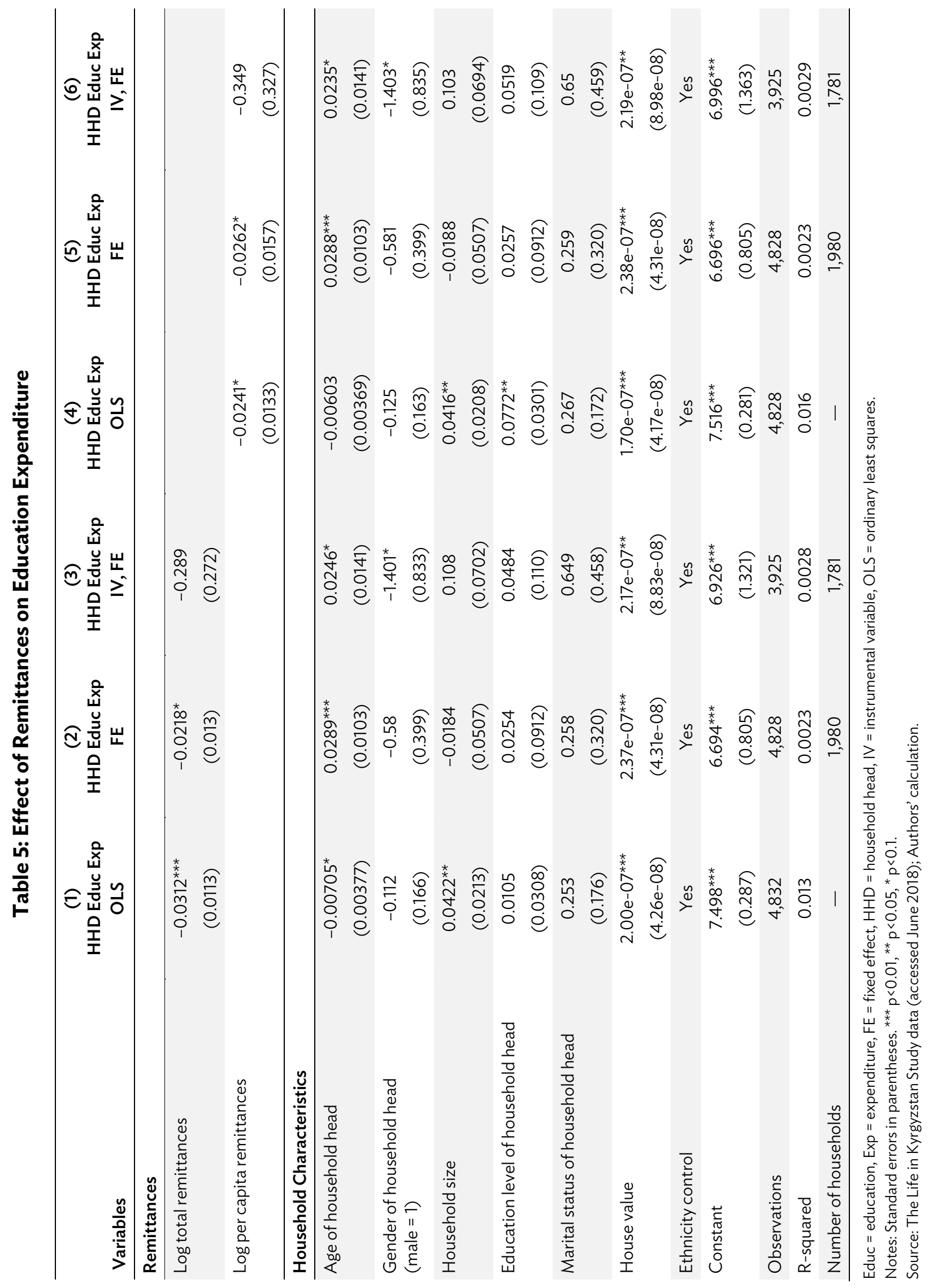


The lack of or close to negative impact of remittances on educational expenditure seems counterintuitive. One explanation may be that remittances might prompt increased expenditure on certain items that requires existing household resources to be drawn into the new items. For example, the household may decide to buy a new car after receiving remittances. However, the remittances may not be high enough to cover the car payments, so the household head will have to cut expenditure on schooling or health care to fund the new car. To understand how household expenditure on other items has changed in response to remittances, a set of regressions of itemized expenditures on remittances is conducted, using distance to the nearest road as instrumental variable (Table 6). ${ }^{7}$ The categorization method of household expenditure items is summarized in Table A5. Table A6 reports the endogeneity corrected results.

We find that remittances have negative impacts on nondurable goods (e.g., clothing, shoes, personal care items) but positive impacts on durable goods (e.g., cars, phones, computers, TV); health care (e.g., medicine, hospital visits); and other expenditures (e.g., house maintenance, recreation, taxes). Interestingly, expenditure on durable goods has the highest elasticity-a $1 \%$ increase in remittances may lead to a $4 \%$ increase in durable goods expenditure. This suggests that the negative response of educational expenditure to remittances may be induced by the large expansion in demand for durable goods. This also suggests an increase in remittances is less likely to lead to a parallel increase in spending on education and nondurable goods because of the greater demand to purchase durable consumer goods. This is consistent with the findings of World Bank (2015), which reports that while being a migrant household correlates with higher consumption, it does not correlate with higher education expenditure (either in total or in per capita terms using OLS estimation controlling for household characteristics).

In addition, noting that the dependency ratio for migrant households is lower than for nonmigrant households, evidence shows that the choice of migration is not necessarily an investment into youth but rather on asset accumulation (World Bank 2015). Meanwhile, Muktarbek kyzy, Seyitov, and Jenish (2015) report partially similar results, noting that remittances have a greater effect on spending on durable goods than education (i.e., a $1 \%$ increase in remittances' share from total income increases the share of expenditure on durable goods by $1.12 \%$ and on human capital by $0.7 \%$ ).

In sum, this paper's findings suggest that migrant households in the Kyrgyz Republic are primarily driven by consumptive investment (i.e., investment in assets and goods that immediately improve the quality of life and standard of living of households) rather than productive investment (i.e., investment in human and physical capital that improves the long-term productive capacity of households). This might be partly attributed to migrant households in the country having few domestic sources of income and social assistance and increasingly becoming dependent on remittance income, which makes them more vulnerable to economic shocks (World Bank 2015). In this regard, remittance income is then more likely to be used for immediate consumption or as a shock absorber substituting for social protection when the domestic labor market or social assistance is poor (Kireyev 2006).

\footnotetext{
This type of instrument has been used before in the literature by Woodruff and Zenteno (2007) for the case of Mexico and by Adams and Cuecuecha (2010) for the case of Guatemala, for distance to the nearest transportation system is a good proxy for migration costs. Since road is the major mode of transportation in the Kyrgyz Republic, the further away a household is from the road system, the lower the likelihood any household member would migrate and hence lower remittances. One potential drawback is that distance to the nearest road tends to be time invariant. In our dataset, however, we do have enough within-subject variation to allow for identification. The change may either be induced by construction of new roads or households moving to new locations.
} 


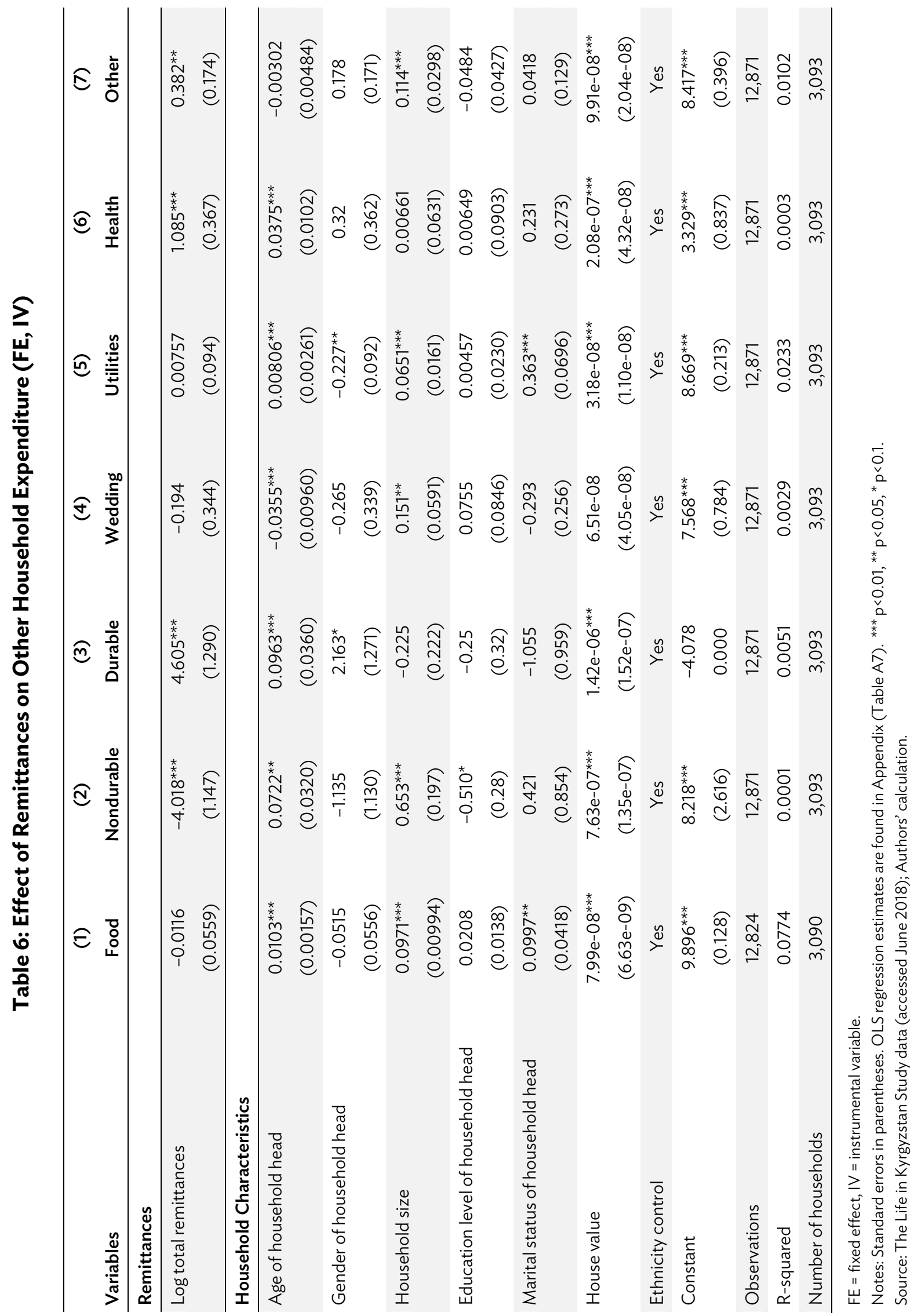


In addition, the pattern of expenditure on durable goods and other items such as recreation and house maintenance-which are often seen as status-oriented consumption goods-may suggest that the receipt of remittances may, at the same time, encourage conspicuous consumption at the expense of long-term productive investments.

On another note, within household characteristics, the finding that older household heads tend to spend more of their budgets on education seems to highlight the factor of maturity in influencing household expenditure and consumption behavior. In addition, the finding relating to investment differences by wealth levels indicates that wealthier households may have better access to credit, allowing them to seize more investment opportunities, including spending on education. Notwithstanding this possibility, the expected returns to education and country-level idiosyncrasies tend to play a large role in determining household education expenditures in the Kyrgyz Republic, especially on tertiary education.

According to a recent study by Yamano et al. (2019), an increasing share of secondary school graduates is opting to leave education, in part due to higher admission requirements in higher education institutions and amid a lack of appropriate employment prospects for university graduates. In addition, despite an expansion in higher education institutions in recent years, their quality remains poor. Even as a university diploma does provide a better chance of being employed, unemployment among graduates remains high, at about $18 \%$ in 2015 . This contextual evidence that the quality of and returns to education are among, if not the major, determinants of Kyrgyz Republic households' expenditure allocation on education is consistent with the findings of Clement (2011) and Brown, Olimova, and Boboev (2008).

\section{Estimation Results (2): Remittances and Educational Outcomes}

While educational expenditure is a good measure on households' investment in human capital, educational outcomes are of utmost importance. This section is an evaluation of the effect of remittances on educational outcomes; in particular, the school attendance rate of school-age children and youth (Table 7). The dependent variable is binary, taking the value of 1 if a person between the age of 5 and 24 attends school and 0 otherwise. Since the dependent variable is at the individual level, per capita remittances -instead of total remittances received-are used as our key independent variable.

The first two columns of Table 7 summarize the estimation results using the full sample, with and without instrumental variables. The coefficient on remittances remains negative and statistically significant regardless of the model used. That is, remittances have a negative impact on children's school attendance rate. 


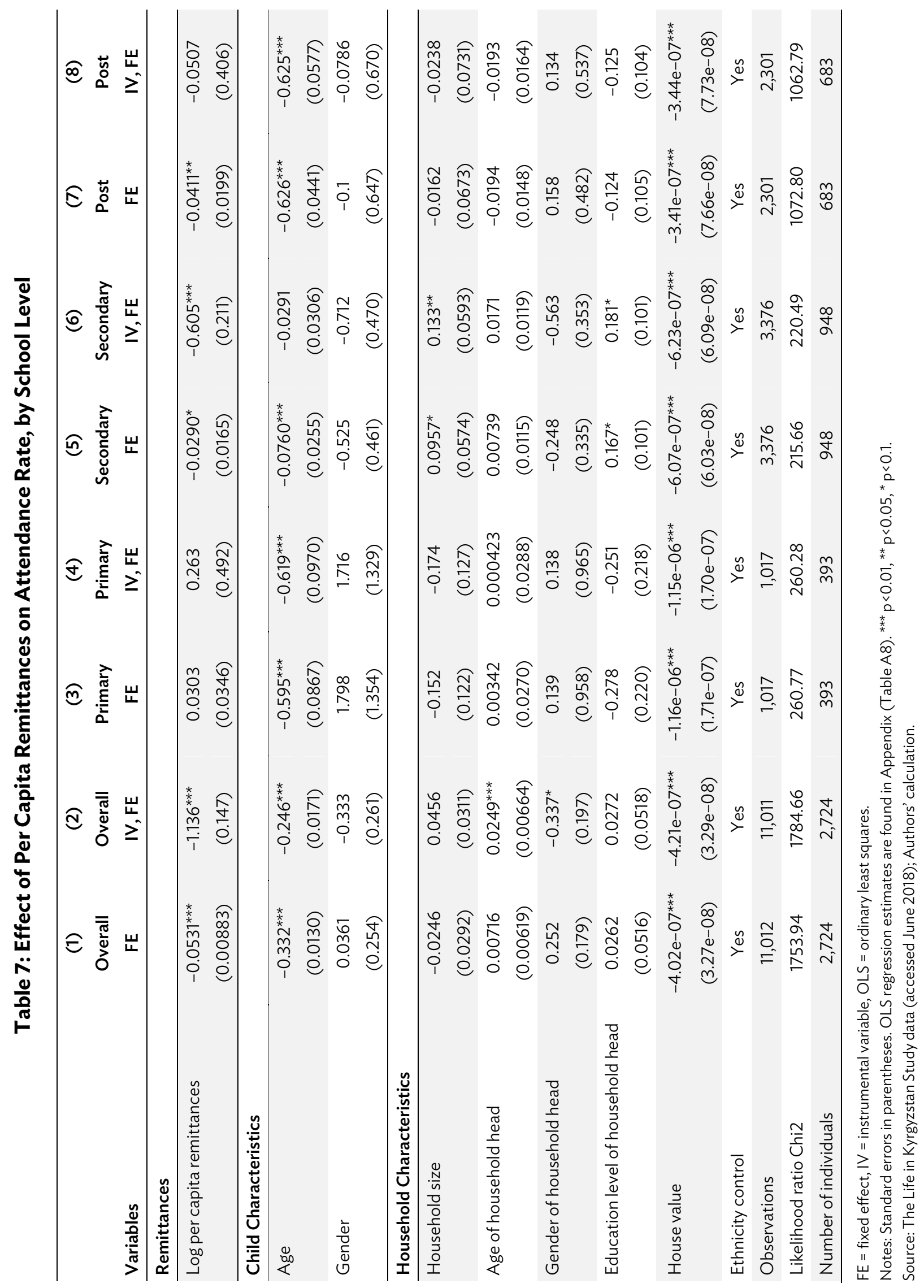


We further breakdown the effects by school level and report them in columns (3)-(8) in Table 7. Regardless of the model used, remittances do not have a statistically significant impact on primary school attendance rate, columns (3) and (4). This is not surprising as primary education is compulsory and free of charge. In terms of the secondary school attendance rate, the effect is, however, negative and statistically significant. This may be associated with the maturity of children of ages 10-17, in that they can substitutes for adult labor. In the Life in Kyrgyzstan questionnaire, household heads are asked to report if, and why, school-age children within their households do not attend school. While "works to support family" is not considered as a reason for any absence from primary school, it is quoted as a reason for about $10 \%$ of cases of secondary school nonattendance. For postsecondary education, the effect seems to be negative but is not statistically significant after correcting for selection bias. One possible explanation rests on the fact that college attendance rate in the Kyrgyz Republic is generally very low. ${ }^{8}$ Therefore, the effects of remittances on such small variation can hardly be identified robustly.

An alternative breakdown method is by compulsoriness, where the school-age children sample is divided into compulsory (ages 6-15) and voluntary ("noncompulsory") attendance (ages 16 and above). The results are reported in Table 8 . For both categories and across specifications used, the impact of remittances on school attendance is uniformly negative and statistically significant. In other words, the existence of compulsory education does not counter the negative impact of migration and remittances on children's educational outcomes. It is understandable that the effects are statistically significant for the compulsory and noncompulsory attendance age groups, since secondary education - the level most heavily impacted by migration and remittances-covers both. In terms of individual and household characteristics, the finding is the same as in the school level breakdown analyses. Older children and children from wealthier families are less likely to attend school, both in compulsory and noncompulsory education.

Table 8: Effect of Per Capita Remittances on Attendance Rate, by Compulsoriness

\begin{tabular}{lcccc}
\hline Variables & $\begin{array}{c}(1) \\
\text { Compulsory } \\
\text { FE }\end{array}$ & $\begin{array}{c}(2) \\
\text { Compulsory } \\
\text { FE, IV }\end{array}$ & $\begin{array}{c}(3) \\
\text { Noncompulsory } \\
\text { FE }\end{array}$ & $\begin{array}{c}\text { (4) } \\
\text { Noncompulsory } \\
\text { FE, IV }\end{array}$ \\
\hline Remittances & & & & \\
\hline Log per capita remittances & $-0.0268^{*}$ & $-0.918^{* * *}$ & $-0.0681^{* * *}$ & $-0.791^{* * *}$ \\
& $(0.0139)$ & $(0.186)$ & $(0.0161)$ & $(0.277)$ \\
\hline Child Characteristics & & & & \\
\hline Age & $-0.0348^{*}$ & 0.04 & $-0.842^{* * *}$ & $-0.774^{* * *}$ \\
Gender & $(0.0205)$ & $(0.0255)$ & $(0.0350)$ & $(0.0422)$ \\
& -0.217 & -0.525 & -0.142 & -0.422 \\
& $(0.363)$ & $(0.370)$ & $(0.576)$ & $(0.585)$ \\
\hline
\end{tabular}

8 In fact, enrollment in tertiary education has been flat since 2009 (World Bank 2015). 
Table 8 continued

\begin{tabular}{|c|c|c|c|c|}
\hline Variables & $\begin{array}{c}(1) \\
\text { Compulsory } \\
\text { FE }\end{array}$ & $\begin{array}{c}(2) \\
\text { Compulsory } \\
\text { FE, IV }\end{array}$ & $\begin{array}{l}\text { (3) } \\
\text { Noncompulsory } \\
\text { FE }\end{array}$ & $\begin{array}{c}\text { (4) } \\
\text { Noncompulsory } \\
\text { FE, IV }\end{array}$ \\
\hline \multicolumn{5}{|l|}{ Household Characteristics } \\
\hline \multirow[t]{2}{*}{ Household size } & -0.00321 & 0.0644 & -0.0506 & -0.0161 \\
\hline & $(0.0458)$ & $(0.0478)$ & $(0.0578)$ & $(0.0611)$ \\
\hline \multirow[t]{2}{*}{ Age of household head } & 0.00769 & $0.0217^{* *}$ & -0.00324 & 0.00885 \\
\hline & $(0.00872)$ & $(0.00920)$ & $(0.0130)$ & $(0.0137)$ \\
\hline \multirow[t]{2}{*}{ Gender of household head } & -0.106 & $-0.551^{*}$ & 0.402 & -0.00859 \\
\hline & $(0.285)$ & $(0.303)$ & $(0.382)$ & $(0.409)$ \\
\hline \multirow[t]{2}{*}{ Education level of household head } & 0.066 & 0.0717 & -0.0337 & -0.0285 \\
\hline & $(0.0765)$ & $(0.0772)$ & $(0.0885)$ & $(0.0877)$ \\
\hline \multirow[t]{2}{*}{ House value } & $-5.65 e-07^{* * *}$ & $-5.89 e-07^{* * *}$ & $-3.03 e-07^{* * *}$ & $-3.26 \mathrm{e}-07^{* * *}$ \\
\hline & $(5.01 \mathrm{E}-08)$ & $(5.08 \mathrm{E}-08)$ & $(6.44 \mathrm{E}-08)$ & $(6.43 \mathrm{E}-08)$ \\
\hline Ethnicity control & Yes & Yes & Yes & Yes \\
\hline Observations & 4,668 & 4,668 & 4,556 & 4,555 \\
\hline Likelihood ratio Chi2 & 253.19 & 277.99 & 1588.19 & 1576.80 \\
\hline Number of individuals & 1,264 & 1,264 & 1,259 & 1,259 \\
\hline
\end{tabular}

$\mathrm{FE}=$ fixed effect, $I V=$ instrumental variable.

Notes: Standard errors in parentheses. ${ }^{* *} p<0.01,{ }^{* *} p<0.05,{ }^{*} p<0.1$.

Source: The Life in Kyrgyzstan Study data (accessed June 2018); Authors' calculation.

The negative effect of remittances on school attendance rate is again counterintuitive, calling for further investigation as to why school-age children in high remittances families are less likely to attend school and, if they are not in school, where was that time spent. To answer these questions, we performed an additional set of analyses, aiming to identify how remittances affect school-age children's time-use pattern.

In the household questionnaire, household heads are required to answer the following three questions: (i) On average, how many hours each day did [CHILD NAME] spend doing homework during the past academic year? ("homework"); (ii) On average, how many hours each day did [CHILD NAME] spend helping at home, family business or farm during the past academic year? ("housework"), and (iii) If any, how many hours a day did [CHILD NAME] work outside of the household for money in the past academic year? ("outside work"). We regress these three measures on per capita remittances using the fixed effects model with and without instrumental variables. The instrument used is the average distance from the household to road, town hall, hospital, market, and so on - the reason being that the average distance is likely to affect the migration cost, and hence remittances, but is unlikely to change the amount of time children spend on homework, housework, and outside work. It must be noted that only children between ages 5 and 17 are included in this analysis since time-use patterns for children beyond 17 years old are not reported. The estimation results are presented in Table 9, with the plain fixed effects model and instrumented fixed effects model compared beside each other. 
Table 9: Effect of Per Capita Remittances on Children's Time-Use Pattern

\begin{tabular}{|c|c|c|c|c|c|c|}
\hline Variables & $\begin{array}{c}\text { (1) } \\
\text { Homework } \\
\text { FE } \\
\end{array}$ & $\begin{array}{c}\text { (2) } \\
\text { Homework } \\
\text { FE, IV }\end{array}$ & $\begin{array}{c}\text { (3) } \\
\text { Housework } \\
\text { FE } \\
\end{array}$ & $\begin{array}{c}\text { (4) } \\
\text { Housework } \\
\text { FE, IV }\end{array}$ & $\begin{array}{c}\text { (5) } \\
\text { Outside Work } \\
\text { FE }\end{array}$ & $\begin{array}{c}\text { (6) } \\
\text { Outside Work } \\
\text { FE, IV }\end{array}$ \\
\hline \multicolumn{7}{|l|}{ Remittances } \\
\hline \multirow[t]{2}{*}{ Log per capita remittances } & -0.000349 & 0.00872 & $0.0153^{* * *}$ & $0.154^{*}$ & -0.00109 & 0.0157 \\
\hline & $(0.00421)$ & $(0.0596)$ & $(0.00551)$ & $(0.0809)$ & $(0.0023)$ & $(0.0320)$ \\
\hline \multicolumn{7}{|l|}{ Household Characteristics } \\
\hline \multirow[t]{2}{*}{ Age } & $0.0999^{* * *}$ & $0.0996^{* * *}$ & $0.173^{* * *}$ & $0.164^{* * *}$ & $0.0240^{* * *}$ & $0.0230^{* * *}$ \\
\hline & $(0.00604)$ & $(0.00706)$ & $(0.00790)$ & $(0.00959)$ & $(0.00324)$ & $(0.00380)$ \\
\hline \multirow[t]{2}{*}{ Gender } & 0.132 & 0.143 & 0.201 & 0.254 & -0.00163 & 0.00436 \\
\hline & $(0.113)$ & $(0.115)$ & $(0.148)$ & $(0.156)$ & $(0.0606)$ & $(0.0618)$ \\
\hline \multirow[t]{2}{*}{ Household size } & 0.00596 & 0.00433 & $0.0338^{*}$ & 0.01 & $-0.0269^{* * *}$ & $-0.0298^{* * *}$ \\
\hline & $(0.0144)$ & $(0.0177)$ & $(0.0188)$ & $(0.0240)$ & (0.00771) & $(0.00950)$ \\
\hline \multirow[t]{2}{*}{ Age of household head } & 0.00264 & 0.00257 & -0.00108 & -0.00246 & 0.00191 & 0.00175 \\
\hline & $(0.00263)$ & $(0.00270)$ & $(0.00344)$ & $(0.00366)$ & $(0.00141)$ & $(0.00145)$ \\
\hline \multirow[t]{2}{*}{ Gender of household head } & $-0.164^{* *}$ & $-0.158^{*}$ & -0.0766 & 0.0104 & -0.0552 & -0.0447 \\
\hline & $(0.0809)$ & $(0.0891)$ & $(0.106)$ & $(0.121)$ & $(0.0433)$ & $(0.0479)$ \\
\hline \multirow{2}{*}{$\begin{array}{l}\text { Education level of } \\
\text { household head }\end{array}$} & 0.0373 & 0.0376 & 0.0261 & 0.0296 & 0.0055 & 0.00593 \\
\hline & $(0.0229)$ & $(0.0229)$ & $(0.0299)$ & $(0.0311)$ & $(0.0123)$ & $(0.0123)$ \\
\hline \multirow[t]{2}{*}{ House value } & $6.18 e-09$ & $6.17 e-09$ & $3.28 \mathrm{e}-08^{*}$ & $3.66 \mathrm{e}-08^{* *}$ & $-1.84 e-08^{* * *}$ & $-1.79 e-08^{* *}$ \\
\hline & $(1.31 e-08)$ & $(1.32 \mathrm{e}-08)$ & $(1.71 e-08)$ & $(1.79 e-08)$ & $(7.00 e-09)$ & $(7.09 e-09)$ \\
\hline Ethnicity control & Yes & Yes & Yes & Yes & Yes & Yes \\
\hline \multirow[t]{2}{*}{ Constant } & 0.33 & 0.326 & $-1.074^{* * *}$ & $-1.028^{* * *}$ & -0.0986 & -0.0932 \\
\hline & $(0.216)$ & $(0.218)$ & $(0.282)$ & $(0.296)$ & $(0.116)$ & $(0.117)$ \\
\hline Observations & 12,413 & 12,408 & 12,413 & 12,408 & 12,413 & 12,408 \\
\hline R-squared & 0.0568 & 0.0569 & 0.1394 & 0.0769 & 0.0052 & 0.0051 \\
\hline Number of individuals & 4,608 & 4,608 & 4,608 & 4,608 & 4,608 & 4,608 \\
\hline
\end{tabular}

$\mathrm{FE}=$ fixed effect, $\mathrm{IV}=$ instrumental variable.

Notes: Standard errors in parentheses. ${ }^{* *} p<0.01,{ }^{* *} p<0.05,{ }^{*} p<0.1$.

Source: The Life in Kyrgyzstan Study data (accessed June 2018); Authors' calculation.

Looking at the first row, while the coefficients on homework and outside work are not statistically significant, the coefficients on housework are significantly positive. This implies that school-age children in households that receive higher remittances spend significantly more time helping at home, the family business, or farm. This result is robust regardless of the model used. The magnitude of the impact looks rather small at first-a 10\% difference in annual remittances translates into a 30-minute a month, or 6-hour a year, difference in a given school-age child's time spent on housework. However, this also implies that if household $A$ receives twice as much remittance as household $B$ does, the child in household $A$ spends 60 hours more on housework annually than the child in household $B$, which is a significant amount of time. 
Our result is consistent with McKenzie and Rapoport (2007), who found that whereas remittances may help relax households' budget constraints, the absence of a full adult labor force calls for child labor as a substitute, alters school-age children's time-use pattern, and ultimately reduces school attendance. In the Kyrgyz Republic, the labor substitution effect seems to outweigh the budget constraint relaxation effect, as households tend to spend extra income on durable goods rather than investing in human capital, as discussed in section IV.C. It is interesting that the labor substitution effect only occurs in housework, not outside work. One reason may be the tightening of regulations on child labor in recent years.

In 2004, the Kyrgyz Republic ratified the International Labour Organization (ILO) Convention for the Elimination of the Worst Forms of Child Labour. In 2011, its parliament strengthened the Criminal Code by increasing penalties for adults found guilty of crimes against children, including enslavement. In addition, the government adopted the 2012-2014 Social Protection Development Strategy and Action Plan, which serves to protect children and families in difficult conditions, including child labor. Such laws and regulations increase the penalties for hiring children in the formal labor market. Housework, as a blind spot of governmental monitoring, is therefore a rather convenient channel of substituting adult labor with child work.

In addition to the remittances panel, the household characteristics panel shows that older children spend more time on all three types of activities-homework, housework, and outside workmost likely because they have more schoolwork to do and, at the same time, are more able than younger children to perform household duties and jobs outside the household. Children in larger households spend less time on outside work, potentially because more adult family members work. Children in households headed by males tend to spend less time on homework, which is an interesting finding with little theoretical foundation. It is likely that female household heads put greater emphasis on supporting children's schooling and education. It is also likely that male household heads tend to spend more time working and have less time for monitoring children's school performance. Lastly, while children in wealthier households spend less time on outside work, they spend more time doing housework.

Moreover, the magnitude of the effect of wealth (proxied by house value) on housework outweighs that of outside work, meaning that children from wealthier households tend to work more. This helps explain the seemingly puzzling negative effect of wealth on school attendance rate: schoolage children in wealthier families are working instead of going to school. The underlying reason is theoretically ambiguous, but it is likely that parents in wealthier families spend more time earning wages, leaving their school-age children to take on domestic responsibilities at home.

Remittances may have different effects on boys and girls (Hanson and Woodruff 2003). We examine if the effects of remittances on school-age children's educational outcomes vary by gender. The theoretical prediction is inconclusive. On one hand, parents may prioritize education for boys, since they have better employment opportunities in many developing countries. On the other hand, boys are a better substitute for farm labor lost due to migration. To empirically determine the relative magnitude of the two effects, we perform two other sets of regressions. First, we examine if remittances have differential impacts on school attendance of boys and girls. Second, we examine if the impact of remittances on children's time-use patterns differs by gender. 
In Table 10, we separate the sample by gender and look at the effects of remittances. The coefficients are uniformly negative and statistically significant, regardless of models used. However, the magnitude of the coefficients for boys, in columns (1) and (2), is larger in absolute value than for girls, columns (3) and (4), and this relationship is true for both plain fixed effects specification and the instrumental variable specification. This implies that although school attendance for both boys and girls is reduced by migration and remittances, the detrimental effects are greater for boys. This might imply that in the Kyrgyz Republic, labor substitutability outweighs the prospect of future employment, which results in boys being burdened more with housework and farm work.

Table 10: Effect of Remittances on Attendance Rate, by Gender

\begin{tabular}{|c|c|c|c|c|}
\hline Variables & $\begin{array}{c}\text { (1) } \\
\text { Boys' Attendance } \\
\text { FE }\end{array}$ & $\begin{array}{c}\text { (2) } \\
\text { Boys' Attendance } \\
\text { FE, IV }\end{array}$ & $\begin{array}{c}\text { (3) } \\
\text { Girls' Attendance } \\
\text { FE } \\
\end{array}$ & $\begin{array}{c}\text { (4) } \\
\text { Girls' Attendance } \\
\text { FE, IV }\end{array}$ \\
\hline \multicolumn{5}{|l|}{ Remittances } \\
\hline Log per capita remittances & $\begin{array}{c}-0.0719^{* * *} \\
(0.012)\end{array}$ & $\begin{array}{l}-1.194^{* * *} \\
(0.208)\end{array}$ & $\begin{array}{c}-0.0289^{* *} \\
(0.013)\end{array}$ & $\begin{array}{l}-1.067^{* * *} \\
(0.208)\end{array}$ \\
\hline \multicolumn{5}{|l|}{ Individual Characteristics } \\
\hline Age & $\begin{array}{l}-0.327^{* * *} \\
(0.0181)\end{array}$ & $\begin{array}{l}-0.237^{* * *} \\
(0.0237)\end{array}$ & $\begin{array}{l}-0.348^{* * *} \\
(0.0195)\end{array}$ & $\begin{array}{l}-0.267^{* * *} \\
(0.0251)\end{array}$ \\
\hline \multicolumn{5}{|l|}{ Household Characteristics } \\
\hline Household size & $\begin{array}{c}0.000424 \\
(0.0418)\end{array}$ & $\begin{array}{c}0.0729 \\
(0.0448)\end{array}$ & $\begin{array}{l}-0.0644 \\
(0.0424)\end{array}$ & $\begin{array}{l}0.00601 \\
(0.0448)\end{array}$ \\
\hline Age of household head & $\begin{array}{c}0.0035 \\
(0.00858)\end{array}$ & $\begin{array}{c}0.0234^{* *} \\
(0.00926)\end{array}$ & $\begin{array}{c}0.0118 \\
(0.00923)\end{array}$ & $\begin{array}{l}0.0278^{* * *} \\
(0.00980)\end{array}$ \\
\hline Gender of household head & $\begin{array}{c}0.232 \\
(0.250)\end{array}$ & $\begin{array}{l}-0.383 \\
(0.275)\end{array}$ & $\begin{array}{c}0.226 \\
(0.266)\end{array}$ & $\begin{array}{r}-0.338 \\
(0.291)\end{array}$ \\
\hline Education level of household head & $\begin{array}{c}0.034 \\
(0.0755)\end{array}$ & $\begin{array}{c}0.0498 \\
(0.0755)\end{array}$ & $\begin{array}{c}0.0185 \\
(0.0719)\end{array}$ & $\begin{array}{c}0.01 \\
(0.0724)\end{array}$ \\
\hline House value & $\begin{array}{c}-4.19 e-07^{* * *} \\
(4.60 e-08)\end{array}$ & $\begin{array}{c}-4.37 e-07^{* * *} \\
(4.59 e-08)\end{array}$ & $\begin{array}{c}-3.92 e-07^{* * *} \\
(4.79 e-08)\end{array}$ & $\begin{array}{c}-4.14 \mathrm{e}-07^{* * *} \\
(4.83 \mathrm{e}-08)\end{array}$ \\
\hline Ethnicity control & Yes & Yes & Yes & Yes \\
\hline Observations & 5,719 & 5,718 & 5,143 & 5,143 \\
\hline Likelihood ratio Chi2 & 971.24 & 971.93 & 794.77 & 821.19 \\
\hline Number of individuals & 1,399 & 1,399 & 1,301 & 1,301 \\
\hline
\end{tabular}

$\mathrm{FE}=$ fixed effect, $I V=$ instrumental variable.

Notes: Standard errors in parentheses. ${ }^{* *} p<0.01,{ }^{* *} p<0.05,{ }^{*} p<0.1$.

Source: The Life in Kyrgyzstan Study data (accessed June 2018); Authors' calculation. 
We are therefore interested in investigating if the larger negative effect of remittances on boys' attendance in school is at least partly explained by the changes in the time-use pattern induced by remittances. To do so, an interaction term-per capita remittances received interacted with gender (boy $=1$ ) -is added in our regression, where the dependent variable is time spent on housework, the only time-use measure that is significantly affected by remittances. ${ }^{9}$ Following our previous approach, only children between ages 5 and 17 are included in the analysis as time-use patterns for children beyond the age of 17 are not reported. Table 11 shows that even as the coefficient on the interaction term in the plain fixed effects model is not statistically significant, it becomes significant when endogeneity bias is corrected. The interaction term is positive, which implies that compared to girls in high remittance-receiving families, boys in the same group tend to spend more time on housework. Empirically, this result supports that the labor substitution effect applies mainly to boys. What is left for further investigation is the pathway through which remittances affect girls' lower attendance rate.

Table 11: Effect of Remittances on Time Use, by Gender

\begin{tabular}{|c|c|c|}
\hline Variables & $\begin{array}{c}\text { (1) } \\
\text { Housework } \\
\text { FE }\end{array}$ & $\begin{array}{c}\text { (2) } \\
\text { Housework } \\
\text { FE, IV }\end{array}$ \\
\hline \multicolumn{3}{|l|}{ Remittances } \\
\hline \multirow[t]{2}{*}{ Log per capita remittances } & $0.0211^{* * *}$ & 0.0533 \\
\hline & $(0.00791)$ & $(0.0978)$ \\
\hline \multirow[t]{2}{*}{ Log per capita remittances $x$ Boy } & -0.0113 & $0.211^{*}$ \\
\hline & $(0.0109)$ & $(0.126)$ \\
\hline \multicolumn{3}{|l|}{ Personal Characteristics } \\
\hline \multirow[t]{2}{*}{ Age } & $0.173^{* * *}$ & $0.168^{* * *}$ \\
\hline & $(0.00790)$ & $(0.00998)$ \\
\hline \multirow[t]{2}{*}{ Household size } & $0.0342^{*}$ & 0.00673 \\
\hline & $(0.0188)$ & $(0.0249)$ \\
\hline \multirow[t]{2}{*}{ Age of household head } & -0.00116 & -0.00175 \\
\hline & $(0.00344)$ & $(0.00379)$ \\
\hline \multirow[t]{2}{*}{ Gender of household head } & -0.0780 & 0.0350 \\
\hline & $(0.106)$ & $(0.126)$ \\
\hline \multirow[t]{2}{*}{ Education level of household head } & 0.0262 & 0.0373 \\
\hline & $(0.0299)$ & $(0.0324)$ \\
\hline \multirow[t]{2}{*}{ House value } & $3.33 e-08^{*}$ & $2.98 \mathrm{e}-08$ \\
\hline & $(1.71 e-08)$ & $(1.89 e-08)$ \\
\hline
\end{tabular}

9 The same regressions for time spent on homework and outside work were performed, and results show no significant difference between boys and girls. 
Table 11 continued

\begin{tabular}{lcc}
\hline Variables & $\begin{array}{c}(1) \\
\text { Housework } \\
\text { FE }\end{array}$ & $\begin{array}{c}(2) \\
\text { Housework } \\
\text { FE, IV }\end{array}$ \\
\hline Ethnicity control & Yes & Yes \\
Constant & $-0.967^{* * *}$ & $-1.011^{* * *}$ \\
& $(0.273)$ & $(0.302)$ \\
Observations & 12,413 & 12,408 \\
R-squared & 0.1431 & 0.0641 \\
\hline Number of individuals & 4,608 & 4,608 \\
\hline FE = fixed effect, IV = instrumental variable. & & \\
Notes: Standard errors in parentheses. ${ }^{* * *} p<0.01,{ }^{* *} p<0.05,{ }^{*} p<0.1$. & \\
Source: The Life in Kyrgyzstan Study data (accessed June 2018); Authors' calculation. &
\end{tabular}

\section{CONCLUSION}

In a country that provides a significant source of migrant labor, and where remittances comprise a significant proportion of household income, examining whether and to what extent remittance income is allocated for human capital investment is vital. More specifically, analyzing the impact of remittances on educational expenditure and educational outcomes among youth is a development concern deserving of empirical investigation. The case of the Kyrgyz Republic is particularly interesting given the critical importance of remittances to the country.

This paper finds that remittances, which constitute a large share of national income, have no or negative effect on human capital investment (i.e., educational outcome and expenditure). This negative effect can be at least partially explained by the large positive effect of remittances on durable goods spending. Moreover, this study finds that remittances have a negative effect on educational outcome; that is, on children's attendance at school. This can be attributed to an increase of child labor in agricultural and farm work, especially for boys.

The main finding of this study calls for actions that could mitigate such negative impacts and come up with ways to incentivize families to invest remittances in education. Intervention programs may be designed to improve financial literacy so the public can better understand the benefits from long-term expenditures (such as on education and health) versus short-term expenditures (such as on durable goods). Subsidizing farm assets and health care may also encourage investing remittances in education.

Furthermore, the study suggests that the existence of legal and institutional frameworks targeting child labor may not automatically lead to better educational outcomes. It is necessary to address gaps in the design and implementation of these frameworks in the Kyrgyz Republic. The government has made efforts to eliminate the worst forms of child labor, including through ratifying all 


\section{ADB Economics Working Paper Series No. 637}

key international conventions ${ }^{10}$ and establishing related national laws, regulations, and policies." However, gaps remain in the coverage and comprehensiveness of national frameworks. For instance, children are required to attend school only until grade 9 , typically when they reach age 14 or 15 . This standard makes children of ages 14 and 15 particularly vulnerable to child labor as school attendance is not compulsory at their age, but they are also not yet legally permitted to work. Nevertheless, the results of this study suggest that encouraging children's school attendance at the cost of housework, including agricultural work, remains challenging.

Lastly, improving the quality of education, which can increase the employability of graduates, could help promote the overall attractiveness of secondary and postsecondary education, and ultimately improve children's school performance and educational outcomes. Increasing public expenditure for curriculum improvement, greater investments in quality teaching, and cultivating partnerships with the private sector are integral not only for improving quality and accessibility in the country's education system but also for tackling the skills mismatch in the labor market.

10 Including the ILO Convention No. 138, Minimum Age; ILO Convention No. 182, Worst Forms of Child Labor; United Nations Convention on the Rights of a Child (UN CRC); UN CRC Optional Protocol on Armed Conflict; UNCRC Optional Protocol on the Sale of Children, Child Prostitution, and Child Pornography; and Palermo Protocol on Trafficking in Persons (as cited by the United States Department of Labor 2017).

1 Including minimum age for work and hazardous work; prohibition of forced labor, child trafficking, commercial sexual exploitation of children, using children in illicit activities, and military recruitment; compulsory education age; and free public education (as cited by the United States Department of Labor 2017). 


\section{APPENDIX}

Table A1: Reliance on Remittances

\begin{tabular}{lcc}
\hline Year & $\begin{array}{c}\text { Overall } \\
(\%)\end{array}$ & $\begin{array}{c}\text { Receiving } \\
(\%)\end{array}$ \\
\hline 2010 & 8.51 & 84.30 \\
2011 & 10.12 & 83.20 \\
2012 & 10.44 & 79.80 \\
2013 & 8.97 & 63.60 \\
2016 & 7.98 & 75.10 \\
\hline
\end{tabular}

Source: The Life in Kyrgyzstan Study data (accessed June 2018); Authors' calculation.

Table A2: Summary Statistics for Regression Variables

\begin{tabular}{lcclc}
\hline Variable & Mean & SD & Min & Max \\
\hline Dependent Variables & & & & \\
\hline Household education expenditure & 9,112 & 12,558 & 0 & 278,900 \\
Non-durable goods expenditure & 23,066 & 25,949 & 0 & 544,000 \\
Wedding expenditure & 9,528 & 23,743 & 0 & 500,000 \\
Utilities expenditure & 21,000 & 52,985 & 0 & $4,812,000$ \\
Other expenditure & 18,346 & 21,688 & 345,000 \\
Food expenditure & 76,154 & 44,406 & 0 & 893,365 \\
Durable goods expenditure & 7,296 & 24,984 & 0 & $1,275,000$ \\
Healthcare expenditure & 4,701 & 9,869 & 0 & 342,000 \\
School attendance rate & 0.564 & 0.496 & 0 & 1 \\
\hline Independent Variables & & & & \\
\hline Total household remittances & 17,789 & 145,774 & 0 & $9,876,000$ \\
Per capita remittances & 3,124 & 27,748 & 0 & $1,411,000$ \\
Age of household head & 52 & 14 & 16 & 105 \\
Percentage of male household heads & $78.8 \%$ & & 1 & 8 \\
Household size & 4.9 & 2.4 & 1 & \\
Household head education level & 4.7 & 1.5 & & \\
Percentage of household heads & $71.0 \%$ & & & \\
married & & & & \\
\hline & & & & \\
\hline
\end{tabular}


26 Appendix

\begin{tabular}{|c|c|c|c|c|}
\hline Variable & Mean & SD & Min & Max \\
\hline House value & $1,185,000$ & $1,488,000$ & 6,000 & $14,000,000$ \\
\hline Age of school-age children & 15.45 & 5.544 & 6 & 24 \\
\hline $\begin{array}{l}\text { Percentage of female school-age } \\
\text { children }\end{array}$ & $50.7 \%$ & & & \\
\hline Hours per day homework & 1.759 & 1 & 0 & 20 \\
\hline $\begin{array}{l}\text { Hours per day house and/or farm } \\
\text { work }\end{array}$ & 1.37 & 1.392 & 0 & 20 \\
\hline Hours per day outside work & 0.0572 & 0.481 & 0 & 10 \\
\hline \multicolumn{5}{|l|}{ Instrumental Variables } \\
\hline Land area and incidences of drought & 16.6 & 84.0 & 0 & 2,895 \\
\hline Distance to the nearest road & 587.3 & $1,316.6$ & 0 & 30,000 \\
\hline Distance to road and other amenities & $2,627.6$ & $3,992.2$ & 0 & $80,599.2$ \\
\hline
\end{tabular}

$\mathrm{SD}=$ standard deviation.

Source: The Life in Kyrgyzstan Study data (accessed June 2018); Authors' calculation. 


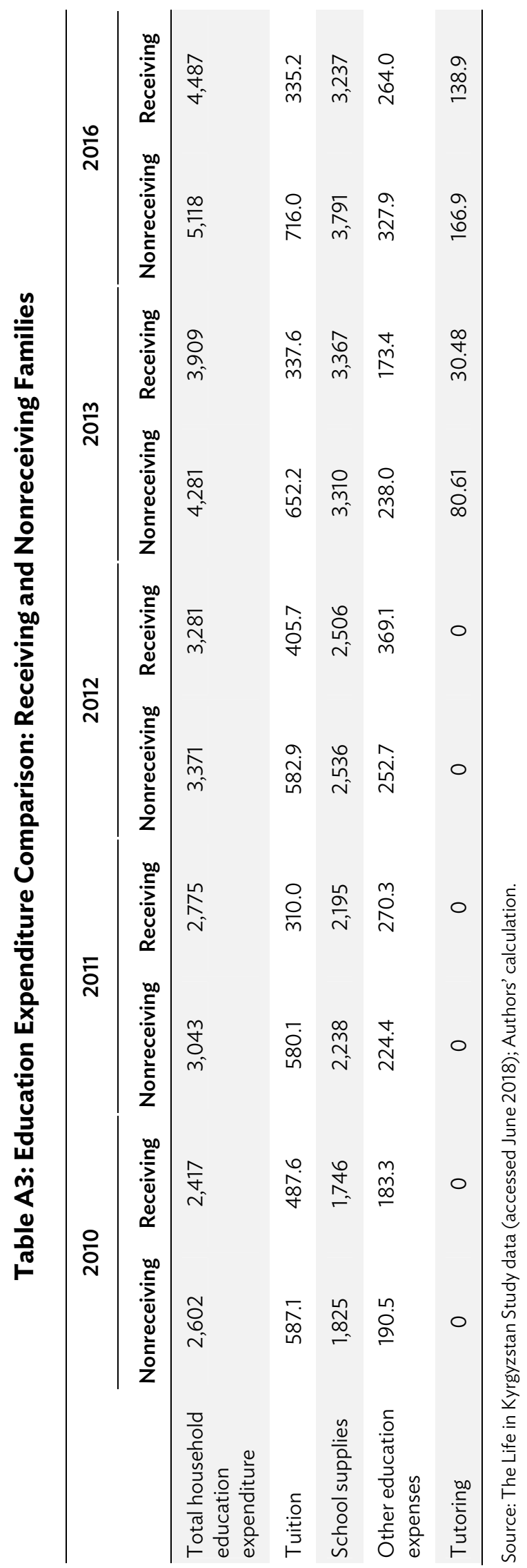


Table A4: First-Stage Results

\begin{tabular}{|c|c|c|c|c|}
\hline & $\begin{array}{c}\text { Educ Expense } 1 \\
\text { Total } \\
\text { Remittances }\end{array}$ & $\begin{array}{c}\text { Educ Expense } 2 \\
\text { Per Capita } \\
\text { Remittances }\end{array}$ & $\begin{array}{c}\text { Other Expense } \\
\text { Per Capita } \\
\text { Remittances }\end{array}$ & $\begin{array}{c}\text { Attendance } \\
\text { Per Capita } \\
\text { Remittances }\end{array}$ \\
\hline \multicolumn{5}{|l|}{ Instrument } \\
\hline \multirow[t]{2}{*}{ Drought $x$ land area } & $0.00246^{* *}$ & $0.00204^{* *}$ & & \\
\hline & $(0.0009)$ & $(0.0008)$ & & \\
\hline \multirow[t]{2}{*}{ Distance to road } & & & $0.0000962^{* * *}$ & \\
\hline & & & $(0.0000)$ & \\
\hline \multirow[t]{2}{*}{ Average distance } & & & & $0.0000614^{* * *}$ \\
\hline & & & & $(0.0000)$ \\
\hline \multicolumn{5}{|l|}{ Covariates } \\
\hline \multirow[t]{2}{*}{ Age of household head } & 0.00532 & 0.00134 & $0.0053^{* *}$ & $0.0171^{* *}$ \\
\hline & $(0.0192)$ & $(0.0160)$ & $(0.0074)$ & $(0.0131)$ \\
\hline \multirow[t]{2}{*}{ Gender of household head } & $-2.328^{* *}$ & $-1.940^{* *}$ & $-0.434^{* * *}$ & $-0.552^{* * *}$ \\
\hline & $(0.7570)$ & $(0.6282)$ & $(0.2428)$ & $(0.2596)$ \\
\hline \multirow[t]{2}{*}{ Household size } & 0.0409 & 0.0195 & $0.1301^{*}$ & $0.0621^{*}$ \\
\hline & $(0.0951)$ & $(0.0789)$ & $(0.0321)$ & $(0.0270)$ \\
\hline \multirow[t]{2}{*}{ Education level of household head } & -0.119 & -0.0874 & -0.0008 & -0.00574 \\
\hline & $(0.1444)$ & $(0.1198)$ & $(0.0668)$ & $(0.0486)$ \\
\hline \multirow[t]{2}{*}{ Marital status of household head } & 0.672 & 0.563 & 0.183 & 0.159 \\
\hline & $(0.5714)$ & $(0.4741)$ & $(0.1951)$ & $(0.1696)$ \\
\hline \multirow[t]{2}{*}{ House value } & $0.000000241^{* *}$ & $0.000000206^{* *}$ & 0.0000 & 0.0000 \\
\hline & $(0.0000)$ & $(0.0000)$ & $(0.0000)$ & $(0.0000)$ \\
\hline \multirow[t]{2}{*}{ Age of child } & & & & $0.0651^{* * *}$ \\
\hline & & & & $(0.0132)$ \\
\hline \multirow[t]{2}{*}{ Gender of child } & & & & -0.326 \\
\hline & & & & $(0.2597)$ \\
\hline Ethnicity control & Yes & Yes & Yes & Yes \\
\hline Cragg-Donald F-statistics & 6.96 & 6.96 & 13.83 & 14.53 \\
\hline P-value & 0.0083 & 0.0084 & 0.0002 & 0.0000 \\
\hline
\end{tabular}

Notes: Standard errors in parentheses. ${ }^{* *} p<0.01,{ }^{* *} p<0.05,{ }^{*} p<0.1$.

Source: The Life in Kyrgyzstan Study data (accessed June 2018); Authors' calculation. 


\section{Table A5: Itemized Household Expenditure}

\begin{tabular}{ll}
\hline Category & \\
\hline Food & Food \\
Nondurable goods & Clothing; shoes; soap, detergents; personal care items and cosmetics \\
Durable goods & $\begin{array}{l}\text { Cell and stationary phone; furniture and other interior equipment; electronics and spare parts; electric } \\
\text { and household appliances; other durable goods }\end{array}$ \\
Wedding & Celebrations, funerals, rituals \\
Utilities & $\begin{array}{l}\text { Electricity; cold water and sewage; hot water; central heating; gas (natural and liquified); coal and other } \\
\text { fuel for heating; construction, maintenance and repair of housing; maintenance and repair of } \\
\text { household vehicles and appliances } \\
\text { Mealth }\end{array}$ \\
Mther & $\begin{array}{l}\text { Mransportation services; all types of taxes (income, land, and so on) and social benefit plan } \\
\text { contributions; entertainment, recreation, eating out; internet use }\end{array}$ \\
\hline
\end{tabular}

Source: The Life in Kyrgyzstan Study data (accessed June 2018); Authors' calculation. 


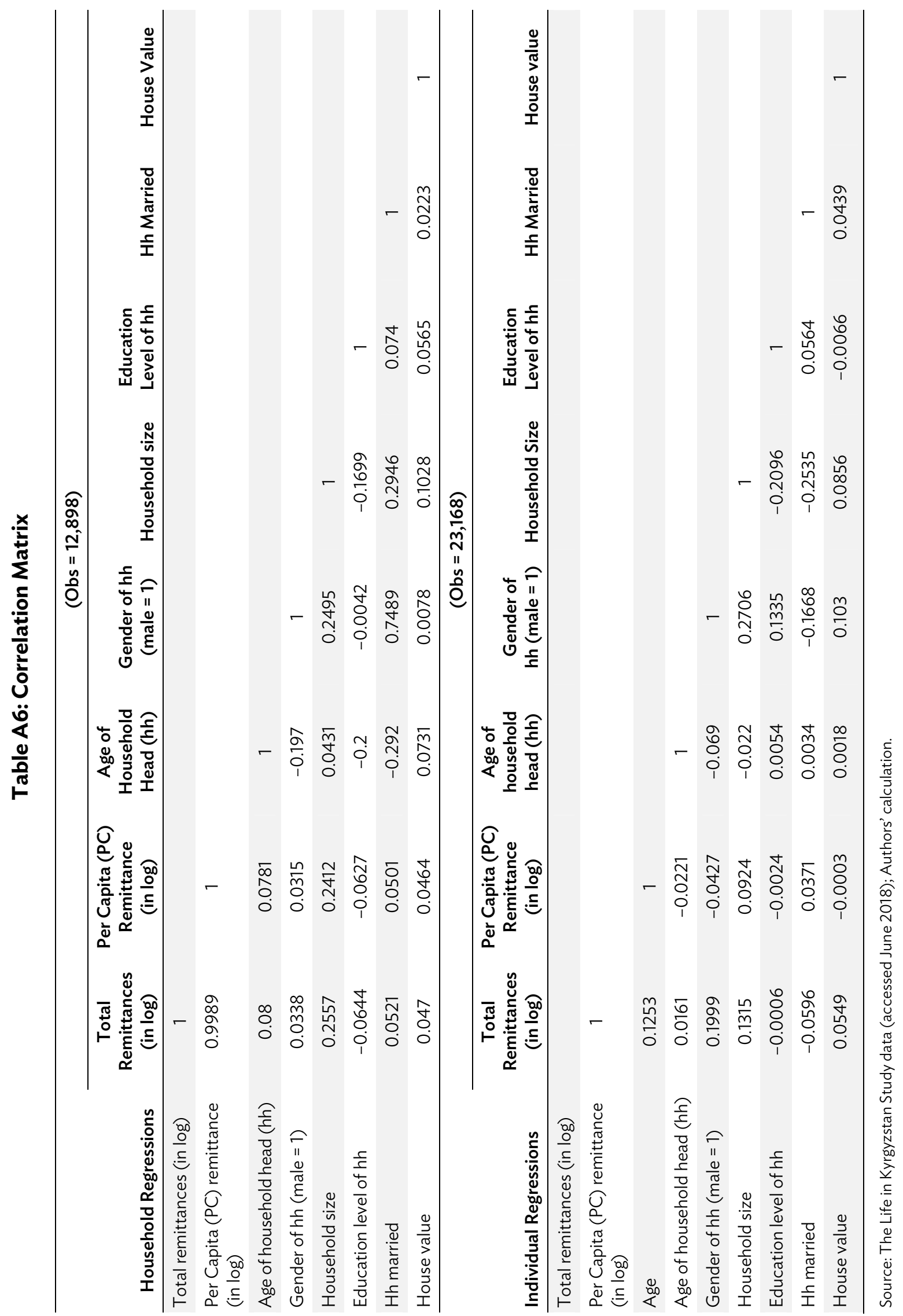




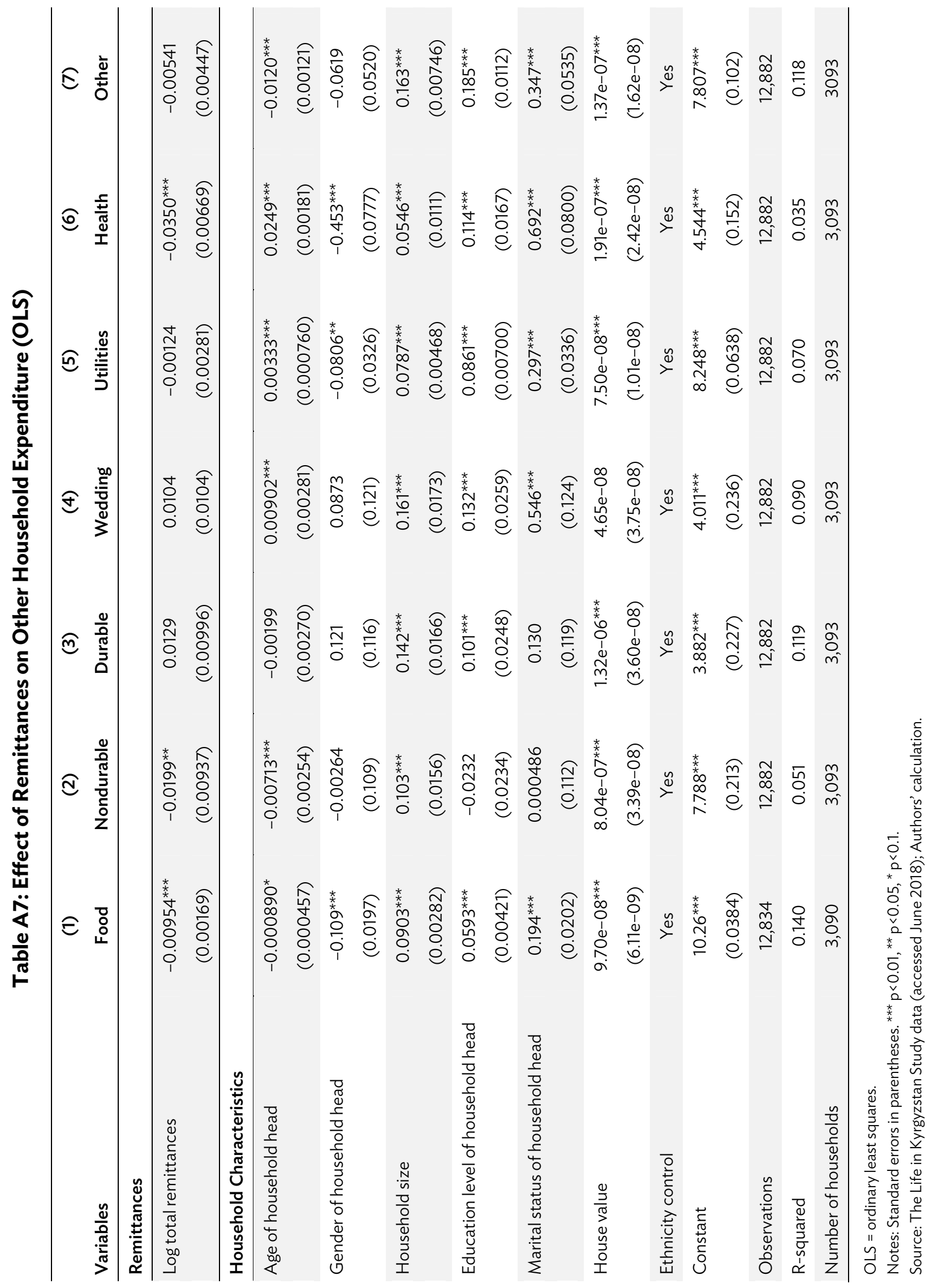


32 Appendix

Table A8: Effect of Per Capita Remittances on Attendance Rate, by School Level (OLS)

\begin{tabular}{|c|c|c|c|c|}
\hline Variables & $\begin{array}{c}(1) \\
\text { Overall }\end{array}$ & $\begin{array}{c}\text { (2) } \\
\text { Primary }\end{array}$ & $\begin{array}{c}(3) \\
\text { Secondary }\end{array}$ & $\begin{array}{l}\text { (4) } \\
\text { Post }\end{array}$ \\
\hline \multicolumn{5}{|l|}{ Remittances } \\
\hline \multirow[t]{2}{*}{ Log per capita remittances } & $-0.00823^{* * *}$ & $-0.00698^{* * *}$ & $-0.00244^{* *}$ & $-0.00780^{* * *}$ \\
\hline & $(0.000793)$ & $(0.00213)$ & $(0.00123)$ & $(0.000954)$ \\
\hline \multicolumn{5}{|l|}{ Child Characteristics } \\
\hline \multirow[t]{2}{*}{ Age } & $-0.0560^{* * *}$ & -0.000227 & 0.00242 & $-0.0491^{* * *}$ \\
\hline & $(0.000489)$ & $(0.00569)$ & $(0.00159)$ & $(0.00182)$ \\
\hline \multirow[t]{2}{*}{ Gender } & $-0.0138^{* * *}$ & 0.00326 & -0.00685 & $-0.0328^{* * *}$ \\
\hline & $(0.00523)$ & $(0.0117)$ & $(0.00713)$ & $(0.00721)$ \\
\hline \multicolumn{5}{|l|}{ Household Characteristics } \\
\hline \multirow[t]{2}{*}{ Household size } & $-0.0120^{* * *}$ & -0.000418 & -0.000147 & $-0.0118^{* * *}$ \\
\hline & $(0.00129)$ & $(0.00301)$ & $(0.00199)$ & $(0.00164)$ \\
\hline \multirow[t]{2}{*}{ Age of household head } & 0.000371 & $0.000869^{*}$ & 0.000485 & 0.000143 \\
\hline & $(0.000234)$ & $(0.000476)$ & $(0.000318)$ & $(0.000351)$ \\
\hline \multirow[t]{2}{*}{ Gender of household head } & -0.00335 & 0.00931 & -0.00378 & $-0.0205^{* *}$ \\
\hline & $(0.00672)$ & $(0.0152)$ & $(0.00948)$ & $(0.00904)$ \\
\hline \multirow[t]{2}{*}{ Education level of household head } & $0.0179^{* * *}$ & -0.000500 & $0.00913^{* * *}$ & $0.0377^{* * *}$ \\
\hline & $(0.00200)$ & $(0.00434)$ & $(0.00276)$ & $(0.00277)$ \\
\hline \multirow[t]{2}{*}{ House value } & $-4.03 e-08^{* * *}$ & $-6.09 e-08^{* * *}$ & $-5.92 e-08^{* * *}$ & $-1.48 e-08^{* * *}$ \\
\hline & $(2.76 e-09)$ & $(6.13 e-09)$ & $(3.83 e-09)$ & $(3.75 e-09)$ \\
\hline Ethnicity control & Yes & Yes & Yes & Yes \\
\hline \multirow[t]{2}{*}{ Constant } & $1.487^{* * *}$ & $0.850^{* * *}$ & $0.827^{* * *}$ & $1.184^{* * *}$ \\
\hline & $(0.0198)$ & $(0.0591)$ & $(0.0335)$ & $(0.0449)$ \\
\hline Observations & 21,696 & 3,769 & 8,390 & 9,537 \\
\hline R-squared & 0.404 & 0.032 & 0.031 & 0.147 \\
\hline Number of individuals & 2,724 & 393 & 948 & 683 \\
\hline
\end{tabular}

OLS = ordinary least squares.

Notes: Standard errors in parentheses. ${ }^{* *} p<0.01,{ }^{* *} p<0.05,{ }^{*} p<0.1$.

Source: The Life in Kyrgyzstan Study data (accessed June 2018); Authors' calculation. 


\section{REFERENCES}

Acharya, Chakra P., and Roberto Leon-Gonzalez. 2014. "How do Migration and Remittances Affect Human Capital Investment? The Effects of Relaxing Information and Liquidity Constraints." Journal of Development Studies 50 (3): 444-460.

Acosta, Pablo. 2011. "School Attendance, Child Labour, and Remittances from International Migration in El Salvador.” Journal of Development Studies 47 (6): 913-936.

Acosta, Pablo, Pablo Fajnzylber, and Humberto Lopez. 2007. "The Impact of Remittances on Poverty and Human Capital: Evidence from Latin American Household Surveys." World Bank Policy Research Working Paper No. 4247.

Adams Jr., Richard H. 2006. "International Remittances and the Household: Analysis and Review of Global Evidence.” Journal of African Economies 15 (2): 396-425.

Adams Jr., Richard H., and Alfredo Cuecuecha. 2010. "Remittances, Household Expenditure and Investment in Guatemala.” World Development 38 (11): 1626-41.

Alcaraz, Carlo, Daniel Chiquiar, and Alejandrina Salcedo. 2012. "Remittances, Schooling, and Child Labor in Mexico." Journal of Development Economics 97 (1): 156-65.

Amuedo-Dorantes, Catalina, and Susan Pozo. 2010. "Accounting for Remittance and Migration Effects on Children's Schooling.” World Development 38 (12): 1747-59.

Anderson, Kathryn, and Bakhrom Mirkasimov. 2010. "Migration, Remittances, and the Human Capital of Children: A Case Study of Tajikistan.” Paper presented at the Fourth Southeastern

International/Development Workshop in Atlanta, GA, December 3. Federal Reserve Bank and Mercer University.

Ang, Alvin P., Guntur Sugiyarto, and Shikha Jha. 2009. Remittances and Household Behavior in the Philippines. ADB Economics Working Paper Series No. 188.

Antman, Francisca M. 2011. "The Intergenerational Effects of Paternal Migration on Schooling and Work: What Can We Learn from Children's Time Allocations?” Journal of Development Economics 96 (2): 200-08.

Bansak, Cynthia, and Brian Chezum. 2009. "How Do Remittances Affect Human Capital Formation of School-Age Boys and Girls?" American Economic Review 99 (2): 145-48.

Böhme, Marcus H. 2015. "Does Migration Raise Agricultural Investment? An Empirical Analysis for Rural Mexico.” Agricultural Economics 46 (2): 211-225.

Bouoiyour, Jamal, Amal Miftah, and El Mouhoub Mouhoud. 2016. "Education, Male Gender Preference and Migrants' Remittances: Interactions in Rural Morocco." Economic Modelling 57 (C): 324-31. 
Bredl, Sebastian. 2011. "Migration, Remittances and Educational Outcomes: The Case of Haiti." International Journal of Educational Development 31 (2): 162-68.

Brown, Richard, Saodat Olimova, and Muhammadi Boboev. 2008. "Remittances and Poverty in Central Asia and South Caucasus (Tajikistan): Country Report on Remittances of International Migrants in Tajikistan." Manila: Asian Development Bank.

Bucheli, José R., Alok K. Bohara, and Matías Fontenla. 2018. "Mixed Effects of Remittances on Child Education." IZA Journal of Development and Migration 8 (1): 1-18.

Bui, Thi Thanh Nga, Thi Thanh Ngan Le, and Kevin James Daly. 2015. "Microlevel Impacts of Remittances on Household Behavior: Viet Nam Case Study.” Emerging Markets Review 25: 176-90.

Calero, Carla, Arjun S. Bedi, and Robert Sparrow. 2009. "Remittances, Liquidity Constraints and Human Capital Investments in Ecuador.” World Development 37 (6): 1143-54.

Chami, Ralph, Connel Fullenkamp, and Samir Jahjah. 2003. "Are Immigrant Remittance Flows a Source of Capital for Development?” IMF Working Paper No. 03/189.

Clement, Matthieu. 2011. "Remittances and Household Expenditure Patterns in Tajikistan: A Propensity Score Matching Analysis.” Asian Development Review 28 (2): 58-97.

Cox-Edwards, Alejandra and Manuelita Ureta. 2003. "International Migration, Remittances, and Schooling: Evidence from El Salvador.” Journal of Development Economics 72 (2): 429-61.

De Brauw, Alan, and Scott Rozelle. 2008. "Migration and Household Investment in Rural China." China Economic Review 19 (2): 320-335.

Frisancho Robles, Verónica, and Ralph Salvador Oropesa. 2011. "International Migration and the Education of Children: Evidence from Lima, Peru." Population Research and Policy Review 30 (4): 591-618.

Funkhouser, Ellen. 2013. "Using Longitudinal Data to Study Migration and Remittances." In Handbook of Research Methods in Migration, edited by Carlos Vargas-Silva. London: Edward Elgar Publishing.

Gibson, John, David McKenzie, and Steven Stillman. 2013. "Accounting for Selectivity and DurationDependent Heterogeneity when Estimating the Impact of Emigration on Incomes and Poverty in Sending Areas." Economic Development and Cultural Change 61 (2): 247-80.

Global Knowledge Partnership on Migration and Development. https://www.knomad.org/ (accessed May 2018).

Gupta, Sanjeev, Catherine A. Pattillo, and Smita Wagh. 2009. "Effect of Remittances on Poverty and Financial Development in Sub-Saharan Africa." World Development 37 (1): 104-15.

Hagedorn, Annelise, Donghui Wang, and Guangqing Chi. 2017. "Remittances and Changing Household Spending Strategies: Evidence from the Life in Kyrgyzstan Study, 2011-2013.” Draft. 
Halpern-Manners, Andrew. 2011. "The Effect of Family Member Migration on Education and Work among Nonmigrant Youth in Mexico.” Demography 48 (1): 73-99.

Hanson, Gordon H., and Christopher C. Woodruff. 2003. "Emigration and Educational Attainment in Mexico." Mimeo. University of California at San Diego.

Kandel, William and Douglas S. Massey. 2002. "The Culture of Mexican Migration: A Theoretical and Empirical Analysis.” Social Forces 80 (3): 981-1004.

Karymshakov, Kamalbek, Raziahan Abdieva, and Burulça Sulaymanova. 2014. "Worker's Remittances and Poverty in Kyrgyzstan." A paper presented at the International Conference on Eurasian Economies, July 2014, Skopje, Macedonia.

Kikkawa, Aiko, Tomoya Matsumoto, and Keijiro Otsuka. 2019. "An Inquiry into the Heterogeneous Outcomes of International Migration: Evidence from Rural Households in Bangladesh.” Journal of Development Studies 55 (10): 2106-28.

Kireyev, Alexei. 2006. "The Macroeconomics of Remittances: The Case of Tajikistan.” IMF Working Paper WP/06/2.

Koska, Onur A., Perihan Özge Saygin, Selim Çağatay, and Andrés Artal-Tur. 2013. “International Migration, Remittances, and the Human Capital Formation of Egyptian Children." International Review of Economics and Finance 28 (C): 38-50.

Kroeger, Antje, and Kathryn H. Anderson. 2014. "Remittances and the Human Capital of Children: New Evidence from Kyrgyzstan during Revolution and Financial Crisis, 2005-2009." Journal of Comparative Economics 42 (3): 770-85.

Lall, Somik V., Selod Harris, and Shalizi Zmarak. 2006. "Rural-Urban Migration in Developing Countries: A Survey of Theoretical Predictions and Empirical Findings." World Bank Policy Research Working Paper No. 3.915.

López-Córdova, José Ernesto. 2006. "Globalization, Migration and Development: The Role of Mexican Migrant Remittances." Inter-American Development Bank, INTAL-ITD Working Paper No. 2652.

Lu, Yao, and Donald Treiman. 2007. “The Effect of Labor Migration and Remittances on Children's Education among Blacks in South Africa." California Center for Population Research Working Paper No. 001-07.

Mansuri, Ghazala. 2006. "Migration, School Attainment, and Child Labor: Evidence from Rural Pakistan.” World Bank Policy Research Working Paper No. 3945.

McKenzie, David, and Hillel Rapoport. 2007. "Network Effects and the Dynamics of Migration and Inequality: Theory and Evidence from Mexico." Journal of Development Economics 84 (1): 1-24.

2011. “Can Migration Reduce Educational Attainment? Evidence from Mexico.” Journal of Population Economics 24 (4): 1331-58. 
McKenzie, David, and Dean Yang. 2010. “Experimental Approaches in Migration Studies.” World Bank Policy Research Working Paper No. 5395.

Muktarbek kyzy, Akylai, Tchoro Seyitov, and Nurbek Jenish. 2015. "Remittances and Expenditure Patterns of Households in the Kyrgyz Republic." The National Bank of the Kyrgyz Republic, Working Paper No. 2.

Munshi, Kaivan. 2003. "Networks in the Modern Economy: Mexican Migrants in the U.S. Labor Market." The Quarterly Journal of Economics 118 (2): 549-99.

Passel, Jeffrey. 2006. Changing Dynamics and Characteristics of Immigration to the United States. Pew Hispanic Center Report. Washington DC: Pew Research Center.

Quisumbing, Agnes R., and Scott McNiven. 2010. "Moving Forward, Looking Back: The Impact of Migration and Remittances on Assets, Consumption and Credit Constraints in the Rural Philippines." Journal of Development Studies 46 (1): 91-113.

Salas, Vania B. 2014. “International Remittances and Human Capital Formation.” World Development 59 (C): 224-37.

Stephenson, Andrew V. and Amanda Wilsker. 2016. "Consumption Effects of Foreign Remittances in Jamaica." International Advances in Economic Research 22 (3): 309-20.

Ukueva, Nurgul, and Charles Becker. 2010. "Private Transfers in Kyrgyzstan's Post Transition Environment: Results from a New Household Panel Dataset.” Migration, Remittances, and Growth. Dissertation by Nurgul Ukueva. Department of Economics, Duke University (2010): 59-83.

United States Department of Labor. 2017. Findings on the Worst Forms of Child Labor: The Kyrgyz Republic. Washington, DC. https://www.dol.gov/agencies/ilab/resources/reports/child-labor/kyrgyzrepublic.

Woodruff, Christopher, and Rene Zenteno. 2007. "Migration Networks and Microenterprises in Mexico.” Journal of Development Economics 82 (2): 509-28.

World Bank. 2015. Labor Migration and Welfare in the Kyrgyz Republic (2008-2013). Washington, DC.

Yamano, Takashi, Hal Hill, Edimon Ginting, and Jindra Samson. 2019. Kyrgyz Republic Improving Growth Potential. Manila: Asian Development Bank.

Yang, Dean. 2008. "International Migration, Remittances, and Household Investment: Evidence from Philippine Migrants’ Exchange Rate Shocks.” Economic Journal 118 (528): 591-630.

Yang, Dean, and HwaJung Choi. 2007. "Are Remittances Insurance? Evidence from Rainfall Shocks in the Philippines.” The World Bank Economic Review 21 (2): 219-48.

Zhang, Hongliang, Jere R. Behrman, C. Simon Fan, Xiangdong Wei, and Junsen Zhang. 2014. "Does Parental Absence Reduce Cognitive Achievements? Evidence from Rural China." Journal of Development Economics 111 (C): 181-95. 


\section{Evaluating the Impact of Remittances on Human Capital Investment in the Kyrgyz Republic}

Remittances from overseas can encourage human capital investment, but empirical studies have shown mixed evidence. This paper uses a 5-year panel dataset in the Kyrgyz Republic to examine the impact of remittances on the human capital formation of school-age children. After correcting for endogeneities with instrumental variables, the study finds that remittances have negative impacts on educational achievement. Extended hours of farm labor by children and increased expenditure on durable goods are identified among recipient households. To mitigate negative effects of remittances on children's learning, the findings call for actions such as financial literacy education and better monitoring of farm labor hours of school-age children.

\section{About the Asian Development Bank}

ADB is committed to achieving a prosperous, inclusive, resilient, and sustainable Asia and the Pacific, while sustaining its efforts to eradicate extreme poverty. Established in 1966, it is owned by 68 members -49 from the region. Its main instruments for helping its developing member countries are policy dialogue, loans, equity investments, guarantees, grants, and technical assistance. 